\title{
Use of Charades in Enhancing Higher Institute Students' Speaking Skills
}

\author{
DALVINDER KAUR A/P KOLDIP SINGH ${ }^{1} \mathbf{8}$ (D) and Azlina Abdul Aziz ${ }^{2} \mathbf{8}$ (D) \\ ${ }^{1}$ Universiti Kebangsaan Malaysia,Bangi, Malaysia \\ ${ }^{2}$ Associate Professor, Faculty of Education, Universiti Kebangsaan Malaysia Bangi \\ $\triangle$ Corresponding Author: DALVINDER KAUR A/P KOLDIP SINGH, E-mail: dalvinsidhu01@gmail.com
}

ARTICLE INFORMATION ABSTRACT

Received: March 05, 2021

Accepted: April 17, 2021

Volume: 3

Issue: 4

DOI: 10.32996/ijels.2021.3.4.3

\section{KEYWORDS}

Charades, Language games, fluency, accuracy, ESL learners
English speaking skill is one of the most challenging skills that has to be taught by teachers, and there are many factors affecting students' low speaking proficiency. Hence, charades are implemented in this study. The purpose of this research is to study the improvement of English-speaking skills among college students through implementing Charades in the classroom. This study consists of two objectives. The first objective is to determine the effectiveness of charades in improving learners' speaking skills, and the second objective is to investigate learners' perception of charades. This study involves 18 students from Chenderoh Community College. Charades were implemented in their speaking lessons. This is single-group quasiexperimental research. Data was collected through pre and post-test and questionnaire. Speaking scores were analyzed through paired T-test. After the data analysis, there is a significant difference between pre and post-test. Students showed a positive perception of charades.

\section{Introduction}

\subsection{Background of the study}

As stated by Aristotle, 'Language is necessary for man to be a rational creature', which means language is a core for the human race. Language enables people to express themselves and create and disseminate their work in the language of their choice (Grenobe A. L \& Whaley J.L, 2006). Only a common language can enhance the growth of civilization if we work in a community not only orally but also in writing (Shirbu, 2019). Even though there are 6500 languages worldwide, only English is a single language that has become the global lingua franca (Northrup, 2013). English has become the universal common language, enabling us to connect globally. English also plays a vital role in main sectors such as medicine, engineering and education (Nishantini, 2018). To be successful in the growth of modernization, it is essential to learn English.

The influence of English in Malaysia began in the early 19th century since Malaysia was colonized by the British. During colonization, English was used as an official language in administration, court and education (Tanaraj,2014). The locals also often use English. As a result, it increases the number of English speakers during that time. Since then, English became the second most important language in Malaysia (Hanapiah, 2004). Even though English was just accepted as a second language in Malaysia, the English language also became the identity of Malaysia due to its colonial past and current important role as one of the instruction languages in primary, secondary and tertiary education (Essays, 2018). The education system in Malaysia focuses on delivering the knowledge of English in all schools and higher institutions. With the rapid growth of globalization, the value of the English language has become essential to learn. Hence a good command of English can increase employability and opportunities for career advancement (Ting, Marzuki, Chuah, Misieng \& Jerome, 2017).
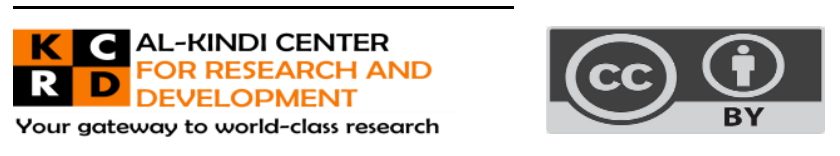

Published by Al-Kindi Center for Research and Development. Copyright (c) the author(s). This open access article is distributed under a Creative Commons Attribution (CC-BY) 4.0 license 
Nowadays, English is used as a medium of communication in everyday situations. Through speaking, we can express our ideas and thoughts. Without proper communication, it will be difficult for us to convey our message in a community. Speaking enables us to pass the message clearly using correct intonation. A good speaker will develop a better understanding and meaningful conversation in any situation. For instance, people at the workplace have to deliver an accurate message to avoid any misunderstanding on a particular topic. Good command of English will help career growth and enhance one's personal life (Qureshi, N.D).

According to Brown and Yuke (1983), 'Speaking is the skill that the students will be judged upon most in real life situations. Therefore, the learners need to learn English speaking skills. Teachers play an important role to prepare an effective learning environment for learners. Since 'Speaking is one of the most difficult skills language learners have to face' (Bueno, Madrid, and Mclaren,2006). Therefore, teachers need to identify the challenges faced by the learners, and teachers need to develop various teaching methods that fit the learners (Rao,2019).

Teachers need to prepare lessons according to 21st'century learning. The classroom should be engaging with skilful activities. To create a student-centred classroom, teachers should cooperate with language games in their lesson. Games are more than just fun. It helps teachers assist them while teaching. According to Jill Hadfield (1990), games are defined as an activity with a set of rules, a goal and an element of fun. Implementation of games in lessons will not only create an active learning environment but also helps teachers and learners to achieve the aim of the lesson. Games are designed to be fun and prevent the class from being boring; hence automatically, students will participate in the lesson, even the shy learners tend to react positively during the lesson (Mei \&Yu Jing, 2000).

Since English is a foreign language, learners face many challenges in the classroom; thus, they tend to develop a stressful learning environment. With the help of games, the stress faced by the learners can be lowered. According to Schultz (1988) 'Stress is a major hindrance in the language learning process. This process [Learning language in a traditional way] is by its nature time consuming and stress-provoking...... raise the stress level to a point at which it interferes with student attention and 6 efficiencies and undermines motivation. One method has been developed to make students forget that they are in class. No doubt that games can help learners be in a calm state of mind and feel comfortable. When learners are in a comfortable zone, they want to learn more. Since they are aware that games are played to have fun, they will play the games by communicating with each other. As a result, they will not be afraid to make any mistakes when using English. In short, learning English speaking skills will take place naturally (Musblat, 2012). Games promote self-learning. When learners are into the games, they will try their best to win the round by using English. Then, without focusing too much on the language, they will utter and communicate with others using English. Real Communication by the given situation will take place. Passive learners or low English proficiency learners will take part equally and try their best to perform their quest. While they are busy playing the games, they will be learning as well (Schultz, 1988).

Everyone likes to win, especially kids. In winning, learners give their level best to complete the task given even though they have to interact in English. This winning desire can turn learners to be very competitive. This helps teachers introduce new topics to students. To win, the game learners will pay extra attention to the lesson. Undoubtedly, students are definitely motivated in English lessons (Avedon, 1971). It helps teachers create a challenging learning environment (Muslabat, 2012).

In addition, using games during the practice stage can enhance learners' speaking skills. Learners are allowed to use English within the context. They can apply and use the knowledge they have learned in a real situation. They will be able to remember and understand better how to use English in real-life situations. Practising communication with their peers helps learners to be confident. They feel more comfortable and familiar with English if they are given a chance to practice often. The right games give the same amount of concentrated practice as a traditional drill, and it offers real communication among the learners (Hadfield, 1990)

Charades is a game involving acting out words, situations, scenarios etc. Charades help learners practice verbal and nonverbal skills (Lopez \& Sukal,2007). Charades allow all the learners to speak in front of the class; thus, it helps learners gain confidence (Latifa \&Nur, 2019). Charades allow learners to be productive rather than being passive during lessons. Charades can be designed according to learners' suitability (Mora,2001).

\subsection{Problem statement}

Malaysia is a multiracial country that consists of different ethnic groups. The first language of Malaysian depends on their ethnic group. Nowadays, most learners are exposed to the English language at an early age through movies, advertisements, songs and many more. Learning English formally will take part later when at the age of six. Learners learn the English language as an additional language. Despite learning English for many years, Malaysian are still known to have limited English proficiency (Musa, Lie \& Azman, 2012). 
Learners find it difficult to speak publicly using English. Few factors cause them to be passive when communicating in English. These factors are cultural factors, linguistic factors and psychological or affective factors (Kukulska-Hulme et al., 2011). Cultural factors involve learners' prior learning experiences and the expectation created (Darmi, 2013). Linguistic factors involve the difference between learners' first language and English language. Learners faced hardship in transferring sounds, rhythms and stress patterns from their first language to English (Darmi, 2013). This occurs when learners lack understanding of the English language's grammatical patterns and sentence structure (Darmi, 3013). On the other hand, psychological or affective factors involve lack of motivation, anxiety and shyness in class when using the English language (Darmi, 2013).

Moreover, there is a strong influence of national language compared to learning English (Musa, Lie \& Azman, 2012). Bahasa Malaysia and the English language have different grammatical rules, morphology and syntax. Learners tend to directly translate from Bahasa Malaysia to English which provides them a wrong idea of using English. Inability to understand English language structure may hinder them in mastering English. In addition, a study from (Lan,1994) highlights the massive use of Bahasa Malaysia in English classrooms. Most of the teachers use Malay to give instructions in English lessons because they believe it is vital for them to understand the context of the lessons and use a common language. Most of the students would act as catalysts in English (llieas,2010).

Furthermore, students only learn or see the language as a pass in the examination. They are not exposed to the importance of English in real-life communication. They fail to connect or apply the knowledge of English which they learn from the classroom to the outside world. With all the rigid rules they have learned, they only see English as "learning a set of language mechanisms with 'fixed' ways of using the language" (Normazidah et al., 2012). As a result, it will prevent learners from mastering the communicative English language proficiently.

Learners also face anxiety when they have to speak in English in front of their peers (Noor hashimah Abdul Aziz, 2007). According to Woodrow (2006), there are three types of anxiety faced by people, including trait anxiety which take place when a person feels uncomfortable in various situations, state anxiety occurs when a person feels anxious for temporary moments only for specific circumstances and situation-specific anxiety refers to when a person feels anxious in a classroom situation. Specific situation anxiety is involved in learning a second or foreign language. In other words, foreign language anxiety or language anxiety is part of specific situation anxiety (Horwitz\&Young,1991; Baker \& Macintyre,2003; Woodrow,2006).

Learners who have anxiety would experience a certain degree of anxiousness in speaking foreign language classrooms, disregarding the environment of class (Horwitz,2001). According to (Darmi\&Albion,2013) language anxiety is developed based on typical self-perceptions, individual beliefs, Fear, and personal feelings towards learning a foreign language. A study conducted to investigate the relationship between anxiety and performance of ESL learners' speaking skills by Woodrow (2006) demonstrates learners' speaking abilities are affected by anxiety. Similar findings found out by (Horwitz\&Cope,1986), learners developed fear in speaking English due to the anxiety. Anxiety plays a part in affecting learners' oral abilities (Philips, 1992). Learning a foreign language becomes more challenging for teachers due to the anxiety (Harry Ayers,2006). Learners develop fear and uneasy in speaking classes (Nur \& et al., 2019).

They feel nervous when they have to use the language, they are not really confident using. Most learners only use English when they have no choice in a confined or limited situation. Otherwise, they tend to use Bahasa Malaysia rather than using English. Hence, it will forbid learners to enhance their speaking skills. Due to the consequence of these factors, learners have to pay a high price when they are unable to market themselves because of the lack of proficient speaking skills (Shuib, 2005). One of the causes of anxiety is when educators expect learners to perform beyond their speaking abilities (Young,1992); thus, it negatively affects learners' motivation. One of the factors that ESL learners in Malaysia cannot understand is that the vast range of vocabulary cannot incorporate other native languages with English (Nur and et al.,2019). As Malaysia consists of most bilingual speakers and due to mixed marriage, speakers become multilingual. Therefore, they are unfamiliar with the language structure of English (Nur, et al, 2019).

Malaysian learners have problems speaking in English, and they cannot communicate in English (Nazirah,2015). Many learners experience a high level of anxiety when asked to communicate in English in a classroom, even though learners in higher institutes face similar problems (Mcroskey,1984). Similar findings by (Chen, 2010) demonstrate ESL learners in his studies are very shy and anxious to speak in English as they are not used to speaking in English. This situation is named communication apprehension as learners face some degree of stress when asked to utter in English suddenly (Nazirah,2015).

Learners' attitude towards learning English plays a vital role. According to (Spolsky,1969), attitude is one of the main factors that affect language learning achievements. Learners should have both attitudes and motivation as learners with a positive attitude and high motivation can meet the expectation of achievement of language learning (Thang Siew Ming, Ting Siew 
Ling,\&Nurjanah Mohd Jafar,2012). Negative attitudes would develop anxiety and stress among ESL learners that prohibit them from learning English successfully. Malaysian learners are not very independent. In other words, learners expect to be "spoonfed" with all the information, notes and slides even at the tertiary level (Florida,1995; Sarjit \& Salasiah, 1996). Learners are very dependent on their educators because they lack effective studying skills and poor time management (Ellis, 1996). These factors make them rely on memorizing rather than apply or practise the principles they learn (Maskuri,1995).

Even at the tertiary level, Malaysian learners have limited knowledge of basic English speaking. Learning a first language or mother language happened naturally in the real world, so it was easy to master it, whereas there is no chance given for some ESL learners to learn English naturally (Nazirah,2015). Most learners use their native language at home and only rely on educators to learn English with other 30 to 50 ESL learners in the classroom (Nazirah,2015). Educators find it challenging to fulfil every learner's weakness in speaking components. Other language skills such as writing and reading skills can be developed with tutoring one to one, but it is very challenging for speaking skill and requires time. The educators usually script a group presentation or even dialogues, so the learners just have to memorize the dialogues (Nazirah,2015). A study carried out by (Lan,1994) illustrates the most common activities that been carried out in speaking classes are reading aloud of long comprehension passages and model dialogues, answering Wh- questions- the answers to these can be read off from the text, giving sample essays writing aloud, reading aloud vocabulary list, two types of drills including repetition of sample sentences after the educators and repetition of a sample of sentences from textbook or storybook. The question arises about ESL learners do not learn authentic speaking as these activities only help learners develop their motor skills of speech and familiarize the linguistic structure of English (Lan,1994; Nazirah,2015). Through these activities, ESL learners are not exposed to real-life communication. They would face difficulties processing their own speech because they are not taught to do so. Learning speaking has become very structured and predictable (Nazirah,2015).

Mainly factors such as cultural, linguistic, psychological, attitude towards learning, motivation, anxiety and educators' role-play an important part in learning a language. All these challenges faced by ESL learners affect them to learn proficiency of Englishspeaking skills successfully.

\subsection{Purpose of research}

The purpose of this research is to study the improvement of English-speaking skills among college students through implementing Charades in the classroom.

\subsection{Objective}

The objective of this research is:

a. To determine the effectiveness of charades in improving learners' speaking skills.

b. To investigate learners' perception of charades.

1.5 Research questions

I. Is there any significance differences between scores of pre and post-test? II. According to the learners' opinion, how charades help them in language development?

\subsection{Hypothesis}

$\mathrm{H}_{\mathrm{o}}$ : There are no significant differences between scores of pre-test and post-test after implementation of charades in the classroom

$\mathrm{H}_{\mathrm{a}}$ : There is a significant difference between pre and post-test scores after the implementation of charades in the classroom. 


\subsection{Conceptual framework}

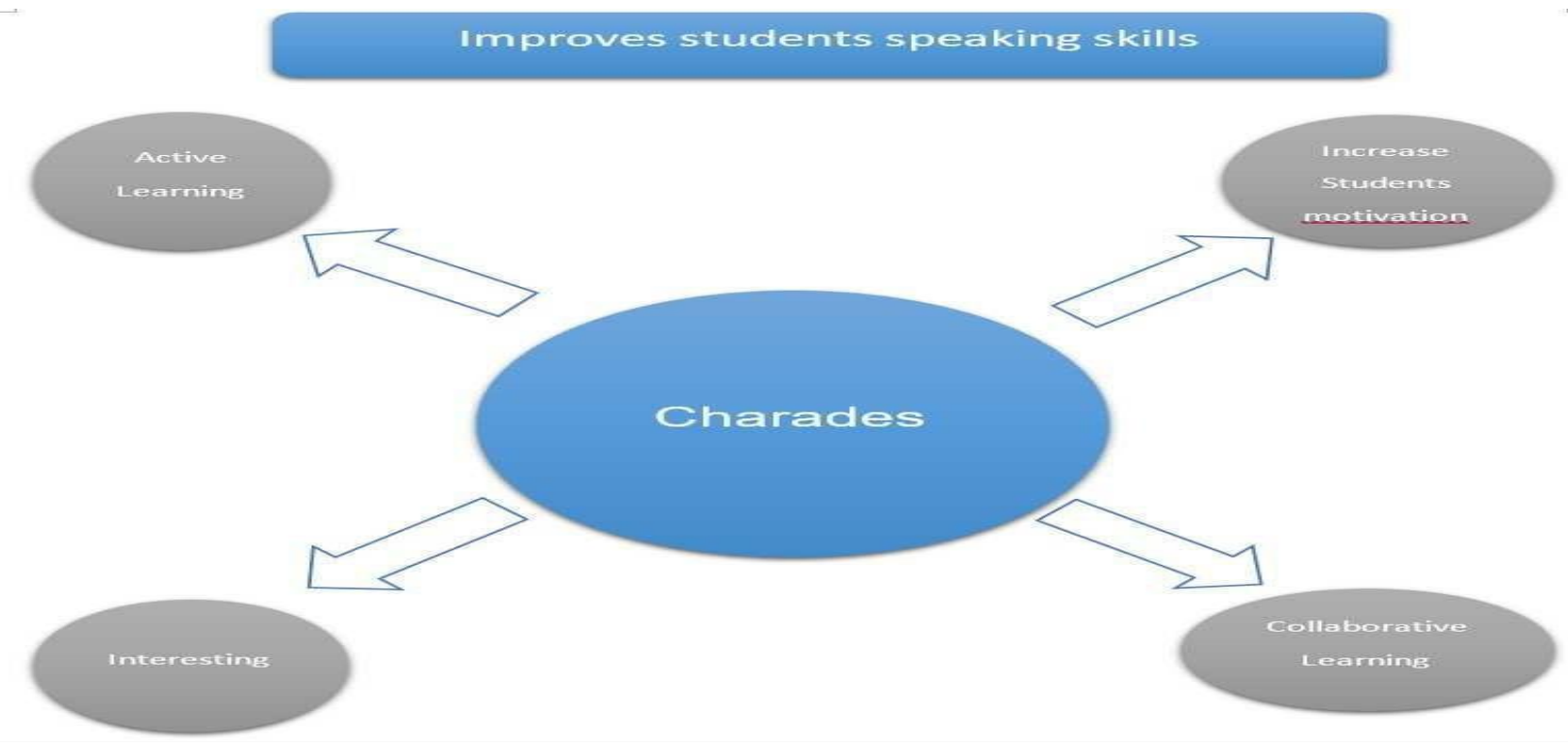

Figure 1 : Conceptual Framework

Active learning involves instructional activities that learners are doing things and aware of (Bonwell\&Elison,1992). Activities that boost high order thinking skills promotes active learning. These can be related to charades; charades require learners to use their own creativity and apply it to complete the task. Thus, charades promote active learning among learners.

Since English is used as a second language in Malaysia, motivation plays an essential role in learning English (Shabban\&Ghaith,2018). Motivation is required to continue learning something new. Hence, it is vital to building interest in English to develop learners' motivation (Santri, suryani \&Dauyah,2019) and it is educators' responsibility to identify what makes learners motivated and unmotivated in speaking classes (Alfulaih \& Elsayed,2018). To measure the success of acquiring a language is through the speaking abilities of ESL learners(Yano,2003). Solid reason and motivation encourage learners to learn a language, and motivation would be a critical factor in sustaining the long learning process. (Dornyei,2005; Zareian\&Jodaei,2015). Classroom learning motivation in learners is varied with each other.

According to Gardner and Lambert (1972), there are two types of motivations in second language learning that affect learners, instrumental motivation and integrative motivation. Instrumental motivation refers to learners' practical needs as a tool to achieve something, the importance of this motivation is to gain something rather than doing for satisfaction whereas integrative motivation refers to learners' attitude towards learning a second language. If learners' attitude is positive towards learning a second language, the learners become part of the culture (Gardner \& Lambert,1972). Gardner (1985) motivation model affects language achievement and Lin (2013) added three components in Gardner (1985)' revised motivation model, which consists of integrativeness, attitudes toward learning and motivation. Integrativeness is an attitude that shows genuine communication, socializing, and the second component refers to how much learners enjoy learning, which involves educator and subject (Lin,2013). The third component of the model refers to learners' satisfaction, efforts, and enjoyment when learning the language. According to Lin (2013), the first two components play a role in maintaining motivation, and the last component plays a part in learners' behaviour towards the target language. Charades is the key to boost motivation among ESL learners.

If language is taught in the traditional method, learners tend to get bored and lose focus (Kruk, 2015). Also, they will view English as a subject to pass in the examination. Educators need to carry out activities like charades in the classroom that involve learners' participation. Learners are more engaged with the lesson, and they have a chance to practice English. So it will make them develop an interest in the classroom. Once learners actively participate in the game and it keeps challenging, they feel more motivated to learn the language. Learning must not always be wearisome. It will demotivate learners to learn in the classroom. In the teaching and learning process, educators are advised not to eliminate the element of fun(Blachowicz\&Fisher,2009). When learners learn English in a fun way, they will enjoy the lesson (Blachowicz\&Fisher,2009). This also helps to reduce the anxiety of speaking or using English (Kruk,2015). 
Collaborative learning involves learners working together to complete a task, solve the problem or create a product in the classroom setting(Saha\&Singh,2016). Collaborative learning forms a platform for learners to achieve academic goals and to develop their language social skills (David \& Nunan,). Vygotsky's sociocultural theory highlights collaborative learning provides how learning takes places with the context and peers (Dillenbourg, 1999). According to Rixon (1981), games is an activity that encourages learners to cooperate to achieve objectives or goals within the limitations.

Through this study, collaborative learning would be illustrated by using language games that would promote learners' social interaction. Games are a learning-centred activity that allows learners to practice and use the language within the educational context (Saha\&Singh,2016). Implementation of charades promotes collaborative learning as the learners need to work together in their respective groups to win the game. As results, learners would learn how to adapt to others in real social settings (Saha \& Singh). Charades offer repeated use of language; thus, it forms a drill to practice speaking English. All these combinations of concepts are correlated, as illustrated in Figure 1. All these concepts of charades help learners' speaking proficiency in English.

\subsection{Significance of the study}

The findings of this research are meant to benefit society as English holds prestigious status worldwide. For fresh graduates to master English communicative skills and market themselves into the job, effective teaching methods should be carried out. Hence, schools that implement language games in their classroom will give proper real-life communication to the students. Thus, students will have a strong English background.

Most learners always view English as a subject to pass without acknowledging the beauty and fun in learning English. Therefore, educators can use language games in the classroom to turn students' negative perspective into positive towards learning English. Language games help educators develop a student-centred classroom, allowing them to practice English with their peers. Once they are familiar with the language, they will be confident and experience less anxiety. Language games are about fun, but they also help educators design their activity that fits all types of learners. There are various types of learners in a classroom. Educators might face difficulty to design their learning activities that suit all the learners. With the help of language games, educators can design any game using their own material based on their learners' interest.

On the other hand, learners will participate fully in learning English when language games are used in class. They will be having fun in class simply by playing games. At the same time, they will be learning and practising English speaking skills. Without them realizing it, they will develop good interaction skills among their peers.

\subsection{Limitations of study}

In this study, there are some possible limitations. Firstly, time constraint. There is limited time given to carry out research. The sample for this study is students from the college community and according to their course structure, they will only have an English period once a week. On top of that, they will only have English for two semesters. Thus, the researcher will face difficulty managing the time. Other than that, the size of the samples is small. There is only a maximum of 35 learners in the college community in a class. Since larger samples give more significant results, this study's results are only applicable to the same age group of learners. Due to these limitations, the findings of results cannot be generalized to specific groups. The sample size and time will impact the results.

\subsection{Operational Definition}

\section{1) Speaking}

Speaking is defined as transmitting information in different situations (Quianthy, 1990). Speaking is an ability to speak fluently and accurately and one can share ideas, deliver information spontaneously (Harmer, 2007). Furthermore, speaking has two functions: transfer of information and interactional, which means the maintenance of social relationships (Brown \& Yule, 1983). Speaking involves transferring information of conversation and a process to express opinion, thoughts, desire in a proper and comprehensible manner (Mories,1966). Speaking also incorporates body languages and style seen as a message (Hybel,2001). Speaking is not all about understanding. It also expresses meanings in a productive manner (Cameron,2001). According to Chaney (1998), speaking is developing and sharing meaning through verbal and non-verbal sign in various situations. Speaking is essentially an instrumental act (Clark\&Clark,1977). According to Vanderkevent (1990), speaking consist of three components the speakers, the listeners and the utterances. The speakers are the person who produces sound and expresses ideas or thoughts to the listener, the listener refers to the person who receives the information from the speaker, and the utterances refer to the production of words, phrases, and sentences from the speakers' mouth.

Speaking is used in many ways by speakers as they promise, bet, advise, warn and exclaim to express emotions; thus, speaking plays a central role in human life. Speaking occurs in the process, which is actively planning and carrying into action. Firstly, speaker plan what they want to utter according to how they want to reply to their listeners, then speakers carry out the plan by saying the segments words, phrases and sentences (Savitri,2013). However, challenges arise when speakers need to choose the 
right words and linguistic form of English. There are five things that the speaker needs to consider: knowledge of the listener, the cooperative of principles, the reality principle, the social context, and the linguistic devices available(Savitri,2013). The planning of speech requires the listener's knowledge, which means how much information the listener knows. The cooperative of principles involves speakers' expectation on listeners' ability to comprehend the information given and the reality principle involves speakers' assumption on listeners to talk about comprehensible events, state and facts (Savitri,2013). The social context involves a difference in vocabulary usage due to different social contexts, and linguistic availability refers to limited linguistics that the speaker acknowledges.

Speaking requires high complex mental activity since it needs the much greater effort of the central nervous system (Bygate, 1998). The process of speaking involves two steps. First, the speaker has to retrieve words and phrases then assembles them into proper sequence sentence structure (Harmer, 2001). Speaking becomes more complex when the speaker has to process the information he listens to and produce speech spontaneously within a limited time (Bygate 1998).

2) Fluency

Fluency of a language is defined as the flow of speech, which means $L 2$ learners have the same level of fluency as native speakers. Fluency is one of the main elements in high proficient speech (Shahini \& Shahamirian,2017). Fluency means using the language spontaneously with confidence (Bailey, 2013) without too much hesitation or too many unnatural pause fillers (Byrne, 1986). Fluency is an important component that needs to be considered in language development (Chambers, 1997). Fluency is an ability to communicate without too much hesitation and too many pause that affects the flow of a speech(Crytal,1977; Bryne,1986; Nation,1991)Fluency occurs naturally when speaker communicate using the targeted language by maintaining the meaningful communication (Richards, 2005). The components of fluency are speech rate, phonation time ratio, pruned syllables, articulation rate, mean length of run, silent pause ratio and filled pause ratio (Thomson, 2015). According to Brown (2001), speech fluency should be focused on beginners and should move forward as the learner tackle the advanced level of language acquisition. Fluency is often viewed as a problematic component of speaking to master because fluency involves native dialect or mother tongue.

3) Accuracy

Accuracy is defined as 'the extent to which the language produced conforms to target language norms'(Yuan \& Ellis, 2003). In other words, speakers use the correct form of language, which relates to the proper use of pronunciation, vocabulary, and grammar.

According to Heaton (1988), accuracy enables learners to manipulate language structure and differentiate between proper and improper linguistic structure. A fluent speech does not include errors affecting phonologic, syntactic, semantic or features of language unit (Byrne,1986).

4) Comprehension

Comprehension means understanding learners about the material of speaking skills (Heroine,2014). Learners often faced difficulty understanding the topic of speaking (Wahyuni \& Yulianti, 2016). During speaking practice, educator finds it hard to correct learners on their understanding of the material as they might feel shy in front of their peers (Wahyuni \& Yulianti ,2016). Educators are advised to give synonyms for specific vocabulary to understand the meaning of the topic or material (Wahyuni \& Yulianti, 2016).

\section{5) Language games}

According to Wittgenstein (1972), a language game refers to the language that is used in the game. A language game is about words and sentences used in the form of a game (Wittgenstein,1972). Theory of language game by Wittgenstein highlights a common goal in all games, which is the language in use, the language of instructions Wittgenstein (1972). According to Hadfield (1999) is classified into two types, which are linguistic games and communicative games. Linguistic games are focused on the structure of language, whereas communicative games are more on the function of language (Hadfield,1999). Hadfield (1999) classified the types of language games, including sorting, ordering, or arranging games, information gap games, guessing games, search games, matching games, labelling games, exchange games, board games, role-playing games, etc., computer games. Language games are classified into two kinds which is a competitive game that ensures learners focus on achieving the goal of the game and there is a cooperative game that sustains the cooperation value in a team. In other words, learners need to work together in order to win the game (Jacob, n.d). Language games need to be designed with clear rules, achievable objectives and arouse learners' interest (Hong, 2002).

\section{6) Charades}

Charades refer to a game that requires the action of acting a word, situation (Teare,2006). According to Ellery (2009), charades is a technique that requires learners to create a mental image of the word or situation that they have acted out (Rafinggi, n.d).In a way, learners tend to remember better (Rafinggi, n.d). Since charades are about using pantomime cues, this engages the learners mentally and physically (Rafinggi, n.d). Without them realizing they will learn and have fun at the same time. 


\subsection{Summary}

This section concludes the background of the study, statement of the problem, purpose of research, objectives, research questions, conceptual framework, the significance of the study, limitations of the study, operational definitions. Chapter 2 will be a literature review and Chapter 3 will consist of methodology. Chapter 4 will be on analysis and discussion as well as chapter 5 will be the conclusion and recommendation.

\subsection{Literature Review}

\subsection{Introduction}

This chapter consists of six sections, types of speaking by Jeremy Harmer, English language in tertiary education in Malaysia, teaching English in tertiary education, theoretical framework, the foundation of games and review on past studies.

\subsection{Types of speakers}

Speaking is about being able to pronounce the words correctly and what to utter in which situation is equally serious as the pronunciation and fluency.

There is a lot more for ESL learners to understand, for example, the function and forms of speaking. According to Harmer(2009), there are two functions: speaking, transitional function, and interpersonal function. Transactional function refers to shares information in order to get a good service. For example, the transitional function is in use while ordering food. Interpersonal function refers to fostering or maintaining a good relationship with others, for instance, having a communication with the shop owner. Harmer(2009) classified two speaking goals: interactive and non-interactive conversation. Interactive conversation occurs when buying newspapers using kiosks, whereas non-interactive conversation occurs when leaving a voicemail using the phone. There is also planned conversation and unplanned conversation. Planned speaking refers to the speaker already prepare what to say before the conversation, in other words. The whole conversation is scripted, for example, speech in the assembly, reporters reading the newspaper, actors acting out their script. For example, speakers would talk on the spot, having a conversation with family members, talking to friends at a party. Educators need to identify the different functions or types of communication they want to teach so that they can choose the right activities based on the focus of the speech. Different functions and events of speech require different types of activities.

\subsection{English language in Tertiary Education in Malaysia}

There are always changes regarding the English language in our education system since we gain independence from the British. These changes occurred in order to prepare Malaysian to compete in the area of globalization (Ganpathi,2012). Language policies play a vital role in forming a nation's identity and building a nation (Tsui \& Tollefson, 2004). The government took one step to form a new national identity after Independence was to make Bahasa Malaysia an official language, whereas English as a second language (Omar, 1992). English is only seen as another subject, but English is an important language because of its economic importance (Government of Malaya, 1956).

The government made few changes that resulted in reducing the use of English. In 1970, as the English language became the second language in Malaysia, the role of English changed from being a medium of instruction to a subject. To fasten the process, all higher institutions changed their medium of instruction fully from English to Bahasa Malaysia in 1983(Gill,2005). There were also minor changes when the time period of teaching English was reduced. Nevertheless, the changes taken by the government towards higher education institutions uphold the importance of English again. English is used worldwide in order to develop economic status. Tertiary education plays an important role (Ganpathi,2012). The government developed an Education Act in 1996 to emphasize the value of English in tertiary education (Too, 2017). Through this act, private universities are allowed to use English as a medium of instruction. This can attract students from overseas and lead Malaysia higher education to be recognized globally(Too,2017).In public universities for courses such as mathematics, science and technology are allowed to use English as a medium of instruction in 2005(Middlehurst \& Woodfield, 2004; Mysinchew.com, 2009).

Few actions were taken to uplift the role of English in the Malaysian tertiary education system by the publication of Malaysian education Blueprint 2015-2025(Higher Education) (Too,2017). According to the (Malaysian Education Blueprint 2015-2025), all Malaysian university students must be equally proficient in Bahasa Malaysia and English and are encouraged to learn the global language. This allows the influence of English throughout Malaysia.

Setting actions like this provides an eye-opener to the students to take learning English more seriously as English at the tertiary level is linked to the role of English in the educational, political, and economic development of Malaysia (Gaudart, 1987; Ridge, 2004).

\subsection{Teaching English in Tertiary Education}

Since the government has emphasized the betterment of the English language among Malaysian students, so National Education Philosophy highlights the requirement of students to join tertiary education in Malaysia to maintain the quality of education. The English language is a prerequisite requirement for admission to almost all the programmes offered in higher 
institutions in Malaysia (Too,2017). Different programmes demand different proficient levels of the English language. To join certificate, diploma, and foundation, students with lower English proficiency, are acceptable, whereas undergraduates and postgraduates require a high proficiency level (Too,2017). To get the qualification of $O$ levels, few tests are accepted, such as the International English Language Testing System (IELTS), the Test of English as a Foreign Language (TOEFL) and the Malaysian University English Test (MUET)(Too,2017) .

There is a range of English courses offered in a higher institute to highlight the prominent status of English. General English language proficiency courses are offered to students that did not meet the programme requirement. Those students who manage to meet the requirement will be offered two English language courses related to their major-one English language course in English for Academic Purposes (EAP). In EAP course, students learn the topic of language related to their area of the course and it is taught to students who need English in their studies, for example, English for Business and English for Engineering (Too, 2017; Dudley Evans \& St.John,1998). There is also an English for Occupational Purposes course offered.EOP course prepares students who use English in their workplace setting (Too,2017). Basically, EOP is especially for students who need to use English in their profession for example, English for Nursing Practice and English for Journalism (Mechraoui, 2011).

Despite all the initiatives taken by the Education department of Malaysia, there are still several graduates with low English proficiency. This situation affects the unemployed rate. In 2005 it was reported there were 60,000 graduates unemployed (Jasin, 2005: Pandain \& Ghani, 2005). In 2016 there were 200,000 graduates reported unemployed (Rebecca,2016). Rate of unemployed increases due to the low proficiency of English, poor communication skills and poor training skills (Lee et al. I, 2008; Hossain et al.,2018). Each individual must play their part to reduce the rate of unemployment in Malaysia (Hossain et al., 2018). University graduates need to meet few requirements to get a job that must have a good command of English, leadership skills, good communication skills, and creative thinking to solve problems (Hossain et al. I, 2018). Graduates need to work on this crucial demand to acquire a job at an early stage.

2.5 Theoretical Framework

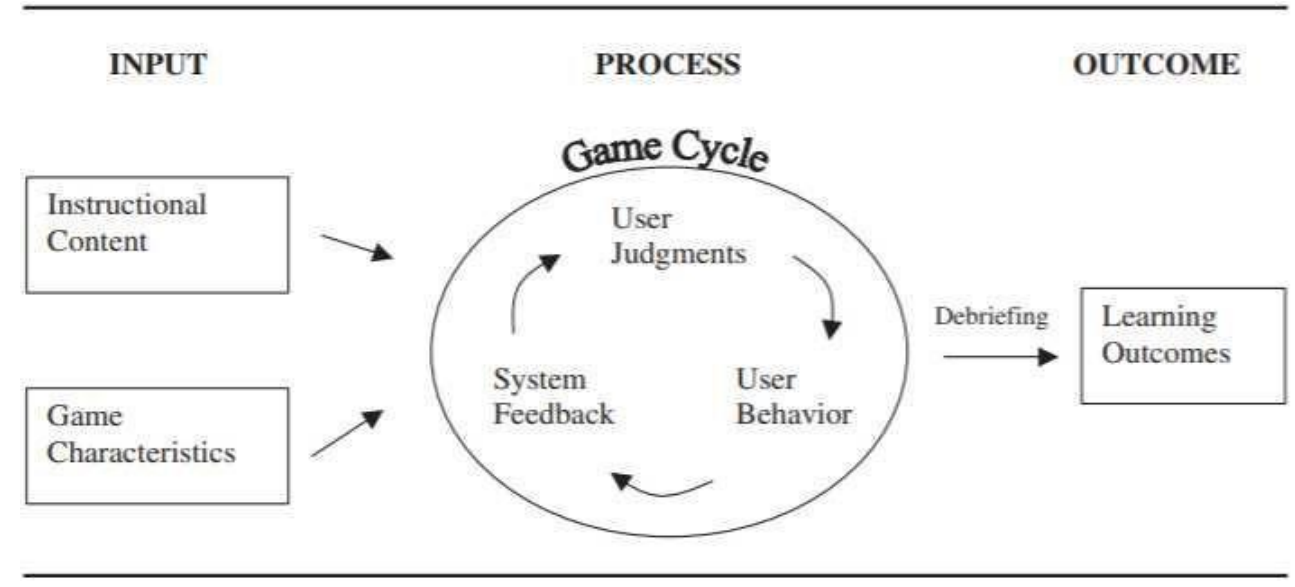

Figure 2: Input-Process - Outcome Game Model

The underlying theories involved in this research is illustrated in Figure 1. The Input- Process-Outcome Game model involves three main levels: input, process, and outcome. Firstly, the game's objective is clearly set, which relates to game features (Garris et al. I, 2002). As for input, the researcher uses questions related to the topic that they have learned as instructional content and rules that are part of the game characteristics. The questions and rules form a cycle that involves user judgments, user behavior and system feedback (Garris et al. I, 2002). User judgments refer to the reaction reacted by the user, for example, what charades makes them feel excited or hyper (Garris et al. I, 2002). User behaviour refers to what kind of strategies they are going to use to win the game and how long it took for a learner to complete the task (Garris et al. l, 2002). Then it linked to system feedback which refers to learners getting feedback to track their scores or progress (Garris et al. I, 2002). This is a continuous cycle of each level. This cycle results from measuring the rate of success incorporating instructional game content and game features (Garris et al. I, 2002). The cycle leads to the end of the game as the learners can achieve the goals and win the game (Garris et al. I, 2002). So from there, researchers can find out that the learners managed to fulfil the specific learning outcomes (Garris et al. I, 2002).

\subsection{The Foundation of Games by Mcgonical}

Games with proper rules and achievable goals provide a good learning experience to all age learners. Games are flexible and are able to fit in according to all different learning styles. According to McGonigal (2016), all the games consist of four main common traits, which are the goal, rules, feedback system and voluntary participation. It is very important to have a goal for any 
game. It can be either educational or mobile games. Players need to work on the specific goal to get results (Mcgonical, 2016). Therefore, educators have to set a particular goal for the learners to achieve and actually give them the idea to focus. Rules are the basic element in any game. These limitations allow players to be more creative and helps them to build strategic thinking in order to play and win the game. Hence, rules help boost creative thinking in learners and this kind of thinking assists learners to solve problems and make decisions (Nurleala, 2018).

The feedback system in a game tells players how close they are to achieve the main goal (Mcgonical, 2016). The feedback system is where players know their scores or points to help them track their progress towards the goal. This system motivates learners to keep moving on in a game. In education games, educators have to display the learners' marks or points of the game visibly to be aware of how much effort to put into achieving the goal. The last main element of games is voluntary participation which means each player must be aware of the goals, rules and feedback system in order for the game to be successful(Mcgonical, 2016). Educationally all the learners have to follow the rules that their educators set to have a proper language game learning session.

Learning language in conventional learning can be less effective when the students become passive and bored (Mapesos, 2017). Games bring happiness to life. When the learners shift their focus to play the game entirely, they will feel happy (Mcgonical, 2016). Happiness brings out the positiveness to learn from learners; therefore, they will be more self-motivated when playing games. Games are not always about winning. There are also times when players face failure. Instead of being disappointed, the player will be more eager to do better (Mcgonical, 2016). Games also have failure feedback as it makes players more engaged and positive about the odds of success (Mcgonical, 2016). Thus, implementing language games in the classroom are more likely to develop students with a creative mindset and a positive attitude towards learning. More often, the players fail. They tend to do better. Thus, if the language games are implemented in classroom settings, students will be more likely to develop a positive attitude than giving up (Mcgonical, 2016).

\subsection{Advantages of Games}

Game is a tool of teaching for teachers and a tool of learning for learners. There are many advantages to use games in the classroom. According to Brewster and Ellis(2002), games add the element of 'fun' in the lesson, changing the learning environment to less stressful. Games also encourage students to practice specific language patterns, vocabulary and pronunciation indirectly in the classroom (Brewster \& Ellis, 2002). Furthermore, Brewster\&Ellis (2002) stated that through games, learners are encouraged to take part, even the shy learners motivated to speak in the lesson. Thus there will be an increase in learners' interaction as fluency speaking practice would take place (Brewster\&Ellis,2002).

\subsection{Review on Past Studies}

\section{Effectiveness of language games}

Language games are not only fun, but it also helps learners to master language skills. A few similar past studies proved that implementing language games in English lessons has helped educators fulfil their objective. To master speaking, learners need to have a good vocabulary, and language games as charades help students master vocabulary in a short period. One research conducted in Branjang, Indonesia, proves that playing charades in the classroom really helps learners master vocabulary. The researcher conducted this research on seventh graders which means Form 1 learners of MTs. Miftahul Khoirot Branjang. This study aims to compare methods of teaching vocabulary, which are charades and conventional method (Hidayati, 2016). So the researcher had two classes, 27 learners in the experimental group and the other 27 learners in the control group. The experimental group was taught vocabulary by using charades, whereas, in the control group, learners were taught vocabulary by using conventional methods (Hidayati, 2016). To measure the comparison, researchers conducted a pre and post-test. Both groups of learners have the same vocabulary proficiency level, as the pretest results show no difference between the two groups. After using these methods, the experimental group showed significant differences compared to the pretest. The t-test results for this group were higher than average, whereas the control group showed not many differences (Hidayati, 2016). Through the data analysis, the researcher concluded charades helps learners to improve their vocabulary, and in the experimental group, they were more actively participating than the controlled group(Hidayati, 2016). To sum up, charades help to develop a positive learning attitude among learners.

Charades boost the process of learning in the classroom because learners will be actively engaged to guess the correct answer. The more often they play, they tend to be more productive. In addition, charades are a helpful learning tool for learners and another research was conducted in Indonesia to prove that using charades in the classroom can improve learners' speaking skills with different ages. A number of 32 tenth grade learners were involved in this research(Puspa,2017). The researcher conducted action research which involved two cycles (Puspa,2017). In both cycles, an observation checklist, questionnaire and test were given to the students. Based on the results, the researcher summed up that learners did improve in their speaking skills(Puspa,2017). When participants are busy playing charades unconsciously, they tend to use English to guess the objects. The more they practise, the better they become (Puspa,2017). The researcher realized participants have more confidence to 
speak in English during lessons compared to previous lessons (Puspa,2017). To add up, learners started showing more interest in learning English and they enjoy English lessons because everyone gets the opportunity to participate in class through charades (Puspa,2017).

Learners cannot remember all the new words taught by the teacher in the classroom because they do not use the word in a situation. Hence they find it uncomfortable to use new words in their daily communication. This situation stops them from speaking in English. By using charades, learners tend to remember better the words (Sari \&Chairani, 2017). Another research conducted on different age group learners in Yogyakarta using charades. A number 62 fourth grader of SD Unggulan Aisyiyah Bantul Yogyakarta were involved in this research. Learners were divided into four classes: a controlled group and the other two of the experimental group (Sari \&Chairani, 2017). Charades were played after learning the lesson in two experimental groups, whereas the researcher used the traditional method to teach the lesson. After analysing data, the researcher could detect significant differences between the four classes (Sari \&Chairani, 2017). Based on the results-controlled group showed a slight improvement compared to the experimental group (Sari \&Chairani, 2017). The experimental group show a big difference between pre and post-test. The researcher concluded; charades help educators to achieve learning objective in classroom. Learners learn in fun and motivating ways to remember better (Sari \&Chairani, 2017). Young learners get bored easily (Harmer, 2007), so using the game to learn is effective (Sari \&Chairani, 2017).

Speaking is usually taught in traditional method; educators usually give a certain topic to learners with some points, and learners have to practice and memorize the points into the presentation (Wahyuni \&Yuliant,2016). So learners must be able to understand the content, pronunciation, grammar of the speech (Wahyuni \&Yuliant,2016). This makes speaking English very complicated for learners and they lose interest. Using charades helps learners to improve speaking skills-another study conducted on 27-second grade learners from MAN 3 Banda Aceh. The aim of this study is to determine the effectiveness of charades in improving learner's speaking skills (Wahyuni \&Yuliant,2016). Learners were divided into two groups, one group learned to speak using charades and another group learned to speak by memorizing the script (Wahyuni\&Yuliant,2016). Pre and post-test of impromptu speech were conducted. The researcher found a significant improvement from the group that use charades compared to the group that learn to speak in the traditional way (Wahyuni \&Yuliant,2016). The researcher concluded that using charades not only improves the learner's speaking ability but also helps learners gain confidence while speaking in front of the classroom(Wahyuni \&Yuliant,2016). Hence learners feel more comfortable using English.

Learners are able to use a variety of sentences by playing charades (Latifa \&Nur, 2019). Another latest study was carried out on 41 seventh graders of SMPN 3 Bulusu. The research was carried out to determine the effectiveness of the guessing game in improving speaking skills and to find out the learners' perception towards implementation of charades in the classroom (Latifa $\& N u r, 2019)$. A number of 20 learners were placed in the experimental group, whereas 21 were placed in the controlled group (Latifa \&Nur, 2019). Pre-test and post-test were given to both groups to determine learners' speaking proficiency. The researcher taught speaking skills in the experimental group by using charades, whereas control groups were taught teachercentred (Latifa \&Nur, 2019). Based on the data collected, the scores of the experimental group were higher than the control group(Latifa \&Nur, 2019). This shows that learners showed improvement in speaking. Through questionnaires, the researcher concluded that learners enjoyed learning while playing charades; hence the lesson becomes interesting (Latifa \&Nur, 2019). Also, charades allow learners to be more productive. (Latifa \&Nur, 2019).

Charades also help students develop good oral presentation skills, which is proven from another related study. A study has been carried out on learners from the engineering programme. Undergraduate learners were introduced to Oral Presentation Charades (Brocato,2014). Learners will be given a scenario of presentation and they have to act out the scenario in groups, whereas the other learners will be the audience (Brocato,2014). The role of the audience is to guess the situation of the presentation (Brocato,2014). This game was played for weeks and it kept becoming challenging (Brocato,2014). This game highlights the difference between what speakers think they are doing and how the audience actually sees them (Brocato,2014).

According to the researcher's observation, in the beginning, most of the learners experienced anxiety as they have to present and act it out in front of the whole class (Brocato,2014). Even the audience responded passively. However, gradually they begin to express themselves fully. Learners gained their confidence and were prepared to present anytime, even if it is an important situation (Brocato,2014). The researcher added that charades give the learner a chance to step out from their comfort zone to have fun during learning and overcome presentation problems (Brocato,2014). Even though the quantitative data do not show obvious improvement, learners did improve their non-verbal skills as consistent eye contact, natural movement and gestures, and minimal distracting tendencies. Through the qualitative data, the researcher concluded that learners formed a strong bond with their batch mates by sharing their experiences playing charades. The researcher concluded Oral Presentation Charade provides positive impacts on his learners as they are confident enough to work on their communication skills (Brocato,2014). 
Another similar research has been carried out to investigate the use of language games towards improving students' speaking skills. Data was collected through observation, interview, questionnaire, pre and post-test. The study was conducted in two cycles, as in the first cycle when games were used. The researcher could not see any success in using games because few students did not actively participate in the lesson. However, in the second cycle, students showed a good response until the students' speaking skills were noticeable. Hence, the researcher concluded that games boost students' interest and motivation. Students improved their fluency, accuracy, pronunciation, vocabulary, and games to provide a platform for students to speak English (Savitri,2013).

All these related studies show that charades positively impact teaching and learning English, especially speaking. Through these studies, it is proven that charades with a clear goal and rules can improve learners' language skills and develop a positive attitude towards learning English regardless of their age.

Learners' opinion towards language games

Integrating language games with speaking lessons helps learners to remember better. According to Hammer\& Lee (2011), the use of language game in the lesson motivates and engages the learners. Thus, language games aid learners to remember the lesson in a fun way and motivate them to master communication in English. The use of language games is not only to aid teachers but also to learners. Few studies have been carried out to find out the learners' point of view towards implementing language games in English lessons.

A study carried out in Malaysia involving 112 primary students aged 9 years old. This research focused on a rural primary school located in Mantin Negeri Sembilan because learners from rural areas do not get much exposure to English media and learners do not use much English apart from English lessons. This research also highlighted the problem statement. Students lack motivation and self-confidence; therefore, they do not participate during English lessons. Hence 40 undergraduates were required to design language games and facilitate the participants. All the language games were designed according to the learners' needs. The process of implementation of language games was carried out for a day. All the primary schools' students were given a chance to participate in playing all eight language games. Data was collected through a self-report questionnaire to find out the students' perception of the games and facilitators. Based on the data analyzed, students have a positive concept of learning English through games. Most of the students were excited and had fun playing games and they did not feel shy to play games. Most of the students feel happy and enjoyed learning English through games and it supports the findings of Ersoz's(2000) who stated that language games are motivating, entertaining and challenging. Some students were exposed to English language games for the first time. The researchers cited these similar findings from (Frome 2003), that language games helps to lower learners' anxiety; therefore, they are not shy to interact using the targeted language. $97.32 \%$ agreed that they got to learn English better through games, and the researchers cited Ersoz's (2000) study to support his findings. Through the research, language games boost cooperation as learners are given a chance to practice language skills. In short, through language games, learners are able to practice their language skills in a stress-free environment. At the end of the study, it has been concluded that language games positively impact students and teachers in the primary school decided to implement language games in their lessons (Tengku, Rosniah \& Stapa,2015).

Another study has been carried out involving elementary students. ESL students were introduced to a language game called twister. Students played the game four times a month. The data was collected through semi-structured interview and observation. The participants feel fun and satisfied by playing twister based on data collected. Since Twister have various colours, word card, it makes the participants calm while using English. The researcher cited a similar finding from Bartle (2004), by playing the game, people feel "fun". Furthermore, participants in the study feel less anxious when they faced difficulties in understanding new words. Usually, they will fear making mistakes when they get to know new words; however, through the game, they did not show and nervousness and continued playing the game. The researcher cited a similar outcome as Yiltanlilar\&Caganaga (2015), using language games in the classroom encourages students to participate and helps to reduce their fear, negative thoughts towards the language. While they are focused on playing the games, they will not think about the mistakes that they might make. The researcher concluded games is an effective tool and learners have feedback towards the language games $(\mathrm{Goscu}, 2016)$.

Another similar study has been carried out, which involves 50 female third level students from Saudi Electronic University (SEU). The study was carried out to improve students' speaking skills through gamification teaching style. The data were collected through observation notes, questionnaire-interview, post-interview and test. Based on data collected, there is a difference between pre and post-tests, which shows students in this study improved their ability. Moreover, the researcher also stated through games, students increase motivation and develop a positive attitude towards speaking English. Students in this study were very motivated when games were introduced in the lesson. The researcher concluded games played a promising role in encouraging students to learn English and also increase their intrinsic and extrinsic motivation (Alfuih\&Elyaseed,2018). 
Another similar study was carried out to find the impact of communicative games on teaching speaking skills. This study involves 36 students from Jakarta. Students were introduced to few games in a lesson. All the data were collected through interview, observation, questionnaire and test. Interview, observation and questionnaire were also given to the teachers. Only tests were designed for students. After implementing the game in the speaking classroom, the results of the post-test are higher than the pre-test. The researcher claimed that students show improvement in speaking skills. Moreover, students developed positive behaviour towards learning as students involve actively throughout the lesson, they are more confident than before, and students have improved their fluency in speaking. The researcher summarizes that using games in the teaching and learning process creates a stress-free environment and reduces boredom and stress while learning English (Dewi, Kultsum \& Armadi, 2017).

\subsection{Methodology}

\section{1 Introduction}

This chapter consists of research design, population and sample, data gathering, and data analysis method.

\subsection{Research Design}

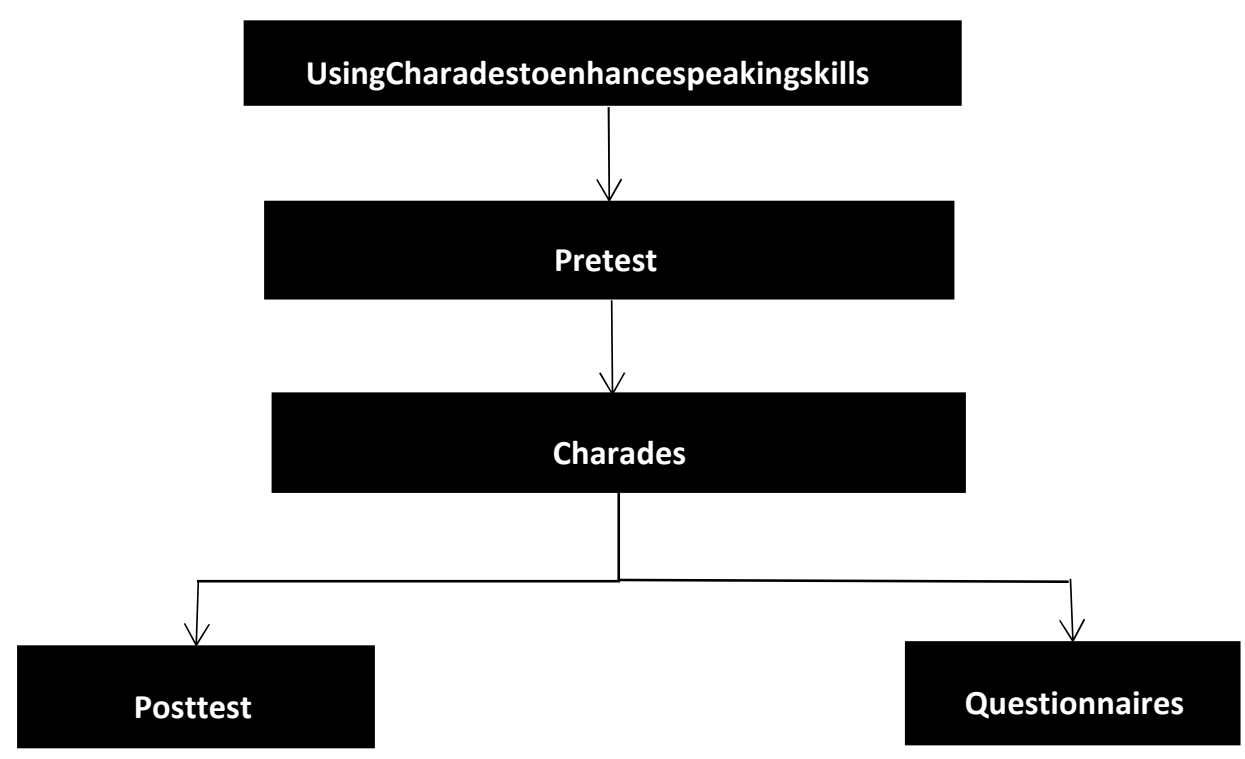

Figure 3:The flow of research

Figure 3 shows the flow of how the research would be carried out. This research has been carried out for 6 weeks. For the first week, students will be given a pre-test. Pre-test in this research is a form of impromptu oral presentation; students are given a question related to the topic and be given 2 minutes to prepare themselves. After the pre-test has been carried out, students will be introduced to the topic, which is Topic 3: Description. This topic is part of their syllabus and at the production stage of the lesson plan, students would play charades. In this stage, students would be using the knowledge taught in the lesson. As the week goes on, the game will be challenging. After four weeks, a post-test will be conducted to compare the scores before and after the implementation of charades in the lesson. The questions for pre and post is the same. After post-test, learners are given a number of twelve questionnaires to find out the learner's perception towards charades. Charades is a mime game, acting about words, sentences but in this research, the researcher modified the rules and the game to suit learners' needs. In this game, charades are played in groups. Each group representative receives a paper that consists of people and objects in which they have to describe it without saying the character's or object's name and the other team have to guess the character. Teammates with the most scores will be the winning teams.

\subsection{Population and Sample}

A number of 18 learners of Chenderoh Community College are involved in this study.

All the 18 students are from the Culinary Arts course and they are semester 1 students. Most of the learners are 18 years old and joined the programme after taking the Sijil Pelajaran Malaysia (SPM) examination. Community College is more focused on skillbased learning (Majdah,2018). According to their syllabus, learners are exposed to core technical skills and general knowledge (Majdah,2018). Communicative English is a part of general knowledge courses and students have to take this course to fulfil the 
requirement. A communicative English course is offered in one semester based on their programme course structure. Communicative English focuses on learners' fluency, accuracy, and speech clarity (Majdah, 2018). Communicative English course is offered to semester one learners from Culinary Arts Programme 2020. Thus, researcher choose the sample through purposive sampling because samples are accessible and one of the topics of the course is suitable to implement charades.

\subsection{Method of Data Gathering}

\subsection{Tests}

Pre and post-test have been carried out. The aim of conducting pre and post-test is to measure the differences of before and after implementing charades. The difference marks of pre and post-test reflect the impact of charades on learners. Learners have to do an oral presentation according to the question and they will be given 2 minutes to prepare the presentation. The oral presentation helps the researcher to test learners' knowledge of vocabulary and understanding of the topic within a limited time. The question of pre and post-test is taken from the syllabus. Learners' evaluations are evaluated based on four main criteria: description, organization of speech, fluency, accuracy, and nonverbal skills. For the mark segregation, $40 \%$ for description, $10 \%$ for organization, $40 \%$ for language and $10 \%$ for nonverbal skills, thus the total score is $100 \%$. The marking rubric is adapted from Jabatan Pengurusan Kolej Komuniti (JPKK).

\subsubsection{Questionnaires}

The aim of questionnaires is to find out the learners' perception towards charades. The researcher chooses questionnaires because they can indicate learners' opinion.The questionnaire consists of 15 questions. All the questions are about learners' response towards charades. The questionnaire is adapted from (Sasidharan \& Eng, 2013). The researcher made minor changes to relate it with this study..Questionnaires are distributed through Google form and there will be time given to answer all the questions. Researchers choose questionnaires to collect the data because data can be collected in a short period of time (Munn \&Drevar,1990). Through questionnaires, researchers can obtain straightforward responses from learners (Munn \&Drevar, 1990).

\subsection{Method of Data Analysis}

This study uses a quasi-experimental method to analyze both data. For pre and post-test, the researcher uses paired T-test through SPSS to analyze the data. The researcher used Excel to calculate the frequency and mean score to analyse questionnaires.

\subsection{Findings}

\section{1 Findings}

1.Is there any significant differences between pre and post-test scores after the implementation of charades?

Data from pre-test and post-test were analyzed to answer RQ1. Table 1 shows students' scores.

Table 1:Students' scores

\begin{tabular}{|l|l|l|l|}
\hline Learner & Pre Test & Post test & Differences (\%) \\
\hline $\mathbf{1}$ & 46 & 79 & 52.8 \\
\hline $\mathbf{2}$ & 44 & 62 & 33.9 \\
\hline $\mathbf{3}$ & 40 & 64 & 29.8 \\
\hline $\mathbf{4}$ & 54 & 84 & 43.5 \\
\hline $\mathbf{6}$ & 40 & 71 & 55.7 \\
\hline $\mathbf{7}$ & 52 & 79 & 41.2 \\
\hline $\mathbf{8}$ & 42 & 74 & 55.1 \\
\hline $\mathbf{9}$ & 51 & 76 & 39.3 \\
\hline $\mathbf{1 0}$ & 46 & 74 & 46.7 \\
\hline $\mathbf{1 1}$ & 48 & 72 & 40.0 \\
\hline $\mathbf{1 2}$ & 46 & 72 & 44.0 \\
\hline $\mathbf{1 3}$ & 40 & 70 & 54.5 \\
\hline
\end{tabular}




\begin{tabular}{|l|l|l|l|}
\hline $\mathbf{1 4}$ & 48 & 79 & 48.8 \\
\hline $\mathbf{1 5}$ & 44 & 74 & 50.8 \\
\hline $\mathbf{1 6}$ & 52 & 76 & 37.5 \\
\hline $\mathbf{1 7}$ & 43 & 73 & 51.7 \\
\hline $\mathbf{1 8}$ & 56 & 89 & 45.5 \\
\hline
\end{tabular}

Table 1 displays the pre and post test scores and the differences in percentage (\%). Before implementing charades, the lowest pre-test score is 40 marks and three students obtained the same lowest score. Meanwhile, the pre-test score is 56 marks, and only one student manages to obtain it. After charades were implemented in the classroom, there were different changes in post-test scores compared to the pre-test. There was 1 student shows the lowest differences between the scores, which is $>20 \%, 3$ students showed differences in post-test that are $>30 \%$. Whereas 8 students manage to achieve $>40 \%$ and 6 students have gain $>50 \%$.In short, there is an increase in differences between pre and post-test scores.

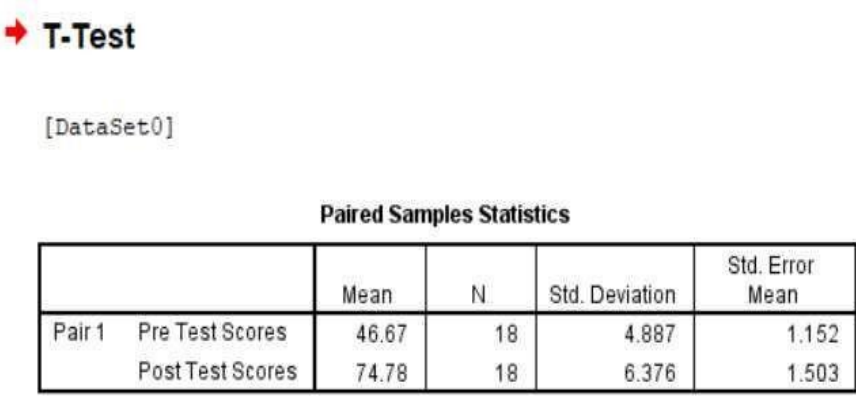

Paired Samples Correlations
\begin{tabular}{|l|r|r|r|}
\hline & \multicolumn{1}{|c|}{ N } & Correlation & \multicolumn{1}{c|}{ Sig. } \\
\hline Pair 1 Pre Test Scores \& Post Test Scores & 18 & .785 & .000 \\
\hline
\end{tabular}

\begin{tabular}{|c|c|c|c|c|c|c|c|c|}
\hline \multicolumn{9}{|c|}{ Paired Samples Test } \\
\hline & \multicolumn{5}{|c|}{ Paired Differences } & \multirow[b]{3}{*}{$t$} & \multirow[b]{3}{*}{ df } & \multirow[b]{3}{*}{ Sig. (2-tailed) } \\
\hline & \multirow[b]{2}{*}{ Mean } & \multirow[b]{2}{*}{ Std. Deviation } & \multirow{2}{*}{$\begin{array}{l}\text { Std. Error } \\
\text { Mean }\end{array}$} & \multicolumn{2}{|c|}{$\begin{array}{l}\text { 95\% Confidence Interval of the } \\
\text { Difference }\end{array}$} & & & \\
\hline & & & & Lower & Upper & & & \\
\hline Pair 1 Pre Test Scores - Post Test Scores & -28.111 & 3.954 & .932 & -30.077 & -26.145 & -30.163 & 17 & .000 \\
\hline
\end{tabular}

Figure 4:Paired Samples Test

Paired T-test through Spss was carried out to determine the differences between pre-test and post-test after using charades in the classroom. Figure 4 shows the results of paired T-test. There is a huge difference between the mean scores. The mean of the post-test score is higher than the mean of the pre-test scores. This shows improved speaking skills as students scored higher marks in the post-test compared to the pretest. The data analysis shows significant differences between pre-test scores and post-test after using charades in the classroom as $\mathrm{t}(17)=-30.163, \mathrm{p}<0.05$. Hence the null hypothesis is rejected.

\section{What are students' perception of charades?}

Data from the questionnaire were analysed to answer RQ2, table 3 and 4 shows the analysis of questionnaires.

Table 3: The number of students

\begin{tabular}{|l|l} 
Male & Female \\
\hline 8 & 10
\end{tabular}


Table 4: Students' perception towards charades

\begin{tabular}{|c|c|c|c|c|c|c|}
\hline $\begin{array}{l}\text { Item } \\
\text { No. }\end{array}$ & Item & $\begin{array}{l}\mathrm{A} \\
(\%)\end{array}$ & $\begin{array}{l}\mathrm{N} \\
(\%)\end{array}$ & $\begin{array}{l}\mathrm{D} \\
(\%)\end{array}$ & $\begin{array}{l}M \\
(\%)\end{array}$ & $\begin{array}{l}\text { SD } \\
(\%)\end{array}$ \\
\hline 1 & The game was enjoyable. & 77.8 & 22.2 & 0.00 & 2.78 & $\begin{array}{l}2.2 \\
6\end{array}$ \\
\hline 2 & $\begin{array}{l}\text { The length of time for playing the game was } \\
\text { suitable. }\end{array}$ & 66.7 & 33.3 & 0.00 & 2.67 & $\begin{array}{l}2.1 \\
6\end{array}$ \\
\hline 3 & The rules of the game were clear. & 72.2 & 27.8 & 0.00 & 2.72 & $\begin{array}{l}2.2 \\
1\end{array}$ \\
\hline 4 & $\begin{array}{l}\text { I took a long time to understand how to play the } \\
\text { game. }\end{array}$ & 27.8 & 55.6 & 16.7 & 2.11 & $\begin{array}{l}1.6 \\
7\end{array}$ \\
\hline 5 & $\begin{array}{l}\text { I like the interaction with other players during the } \\
\text { game. }\end{array}$ & 72.2 & 27.8 & 0.00 & 2.72 & $\begin{array}{l}2.2 \\
1\end{array}$ \\
\hline 6 & I am active during the game. & 61.1 & 38.9 & 0.00 & 2.61 & $\begin{array}{l}2.1 \\
1\end{array}$ \\
\hline 7 & The game keeps me alert. & 72.2 & 22.2 & 5.6 & 2.67 & $\begin{array}{l}2.1 \\
9\end{array}$ \\
\hline 8 & I enjoy playing the games & 77.8 & 22.2 & 0.00 & 2.78 & $\begin{array}{l}2.2 \\
6\end{array}$ \\
\hline 9 & The game motivates me to learn English. & 100 & 0.00 & 0.00 & 3.00 & $\begin{array}{l}2.4 \\
5\end{array}$ \\
\hline 10 & The game motivates me to use English. & 88.9 & 11.1 & 0.00 & 2.89 & $\begin{array}{l}2.3 \\
6\end{array}$ \\
\hline 11 & I feel confident to speak in English during the game. & 77.8 & 22.2 & 0.00 & 2.78 & $\begin{array}{l}2.2 \\
6\end{array}$ \\
\hline 12 & The game encourages teamwork. & 94.4 & 5.6 & 0.00 & 2.94 & $\begin{array}{l}2.4 \\
0\end{array}$ \\
\hline
\end{tabular}

${ }^{*} D=$ Disagree,$N=$ Neutral,$A=$ Agree,$M=$ Mean, $S D=$ Standard Deviation

Table 4 shows students' response for the questionnaire given to them. Through the analysis, most of the responses are in a mean score ranging from 2.00 to 3.00 . The highest responses were gained from items number 9 'The game motivates me to learn English' (100\%) followed by item number 12 'The game encourages teamwork (94.4\%) and item number 10 'The game motivates me to use English' (88.9). The highest negative response was gained from item number 4 'I took a long time to understand how to play the game' (16.7\%), which means $16.7 \%$ of students did not have trouble in understanding the rules of the games whereas the rest $55.6 \%$ responses were neural and the remaining $27.8 \%$ took a long time to understand the rules of charades. Overall, most of the students have a positive perception towards charades.

\subsection{Discussion}

5.1 Discussion of the findings

This research consists of two research question. The first research question is to identify any significant differences between pre and post-test scores. The data analysis clearly shows that students did improve their speaking after playing charades during the lesson. Students were tested by four components description, organization, language and presentation skills.

"Erm...the person.....Shahmi...........My best friend. He is a teenager ..He has coklat air.. He have short hair.....She ermm have short air. She have long eyes and the black eyes." 


\section{Excerpt of pretest}

"The person I admire is Shahmi. He is a very good friend of mine. He is 18 years old and he is a Malaysian. His height is $182 \mathrm{~cm}$. He has short brown curly hair. He also has small black eyes. His nose is pointed."

Excerpt of post-test

Both excerpt of dialogues belongs to student number 5. This particular student's excerpt was chosen because his scores showed the most difference between pretest and post-test. During the pretest, the student manages to describe his favourite person but with minimally adequate content and the use of Bahasa Malaysia is used. There is a flow of ideas and points for the organisation column, but there is a lack of progression of ideas. Moreover, during the pretest, the student kept having a long pause before he began the sentence and did not pronounce the word hair accurately. He is keeping pronouncing it as air instead of hair. The student did not have a constant intonation. Furthermore, the student used minimum and straightforward vocabulary. Student wrongly uses the pronouns. Instead of using "he", he used "she". There were also numerous grammatical errors in his speech. As for the presentation skills, the students spoke inaudibly most of the time and had no eye contact with the audience.

After playing charades, the student describes his favourite person with adequate, relevant content. As charades were played a few times during the research, students were allowed to keep describing, so practising English helps students get familiar with the topic and, in this case, it would be familiar with describing. Hence it shows there is improvement in the topic descriptions. These results aligned with (Puspa, 2017) as the studies show significant improvement in speaking skills after practising charades in the lesson as we expose students to real-life communication, so they know how to use English in a real-life situation. In posttest, the student manages to display the points cohesively with a minimum logical progression of ideas. If we compare the extract of pretest to extract of post-test, there are a number of points and they are organized with a flow in post test's extract.

Furthermore, during the post-test of speaking skills, the student succeeded in speaking smoothly and there were no long pauses or hesitations to speak after playing charades. The student's intonation was occasionally accurate as he tried to adjust his pitch according to the points he was delivering. The student's pronunciation was accurate most of the time. Earlier, he mispronounced the word "hair" and during the post-test, he did not repeat the same mistake. Overall, the student has improved his fluency after playing charades. There is a parallel study that shares the same findings (Savitri,2013), who stated using language games in the production stage of a lesson plan could improve students' fluency and pronunciation, students will be less likely to memorize the expressions during speaking or oral presentation because it will occur naturally as they given the opportunity to practice the language throughout the lesson.

The student used simple sentences but with some minor grammatical errors. A grammatical error occurred when the student did not use a possessive pronoun. Instead of using "his height", he said "he height". The student uses a fair range of vocabulary as he said words like "curly, pointed". Moreover, the student showed knowledge in the order of adjectives when he describes the length, colour and type of hair, and eyes in a sentence accurately. This is evidence that student number 5 has improved his speaking skills after playing charades. Similar results shared by Bafadal, Humaira and Nurmasitah (2018), students understand the meaning of words better and spelling through charades, earlier students just repeat the words after the educator, but through charades, they were given a chance to use those words so in order to use the word in a speech one must understand and know how to apply it. This finding also supported by Hidayati (2016), who stated students could remember the vocabulary easily through charades, and the process of learning vocabulary becomes easier. In short, charades encourage students to improve their range of vocabulary.

The student showed some non-verbal skills during the presentation. During post-test, the student speaks most of the time audibly and has appropriate pauses. Student 5 also manage to maintain eye contact for some time and he tried to have some hand gestures. Hence the student did improve his non-verbal skills after the implementation of charades. Research from Brocata (2014) shows that participants could have consistent eye contact and natural movements and gestures when they are after playing charades. It is supported by Sari and Chairani(2017), who stated charades not only helps students to improve vocabulary but also put non-verbal skills into practice.

According to the learners' opinion, the second research question is how charades help them in language development, and a questionnaire was given to all the students to answer the second research question. After collecting the data, all the students responded that charades help increase their motivation to learn English and some of the students agree to charades motivates them to use English in their conversation. This finding supports the findings from Alfulaih and Elsayed (2018), who stated games play a promising role in boosting learners' motivation and creating an exciting environment to learn English as using the right game in the lesson plan developed motivation in students to communicate in English with their friends, and clearly shows students have a positive respond and attitude after the implementation of games in the classroom. Furthermore, when the 
students are motivated, it will affect language achievement (Gardner,1985). Hence automatically, they improve their speaking proficiency.

Another top response from students towards charades where charades encourage teamwork. Charades is a game played in groups and cooperation is essential to win the game. The rules of charades bound the students to interact and communicate English in a group together; thus, their bond within the students grow stronger. When everyone has to communicate, students feel less fear of communicating in English because they would be in a group. This outcome aligned with Brocato (2014), who stated in his study, students formed a strong bond by sharing their experiences through playing charades.

Students also responded that the game was enjoyable and fun playing games. This finding aligned with the study of Gozcu's (2016), who stated language games ensure students feel relaxed; thus, students feel more comfortable and want to learn more. Games are naturally fun so mechanically. Students feel enjoyment when they play games. What makes the situation more interesting is students have fun while learning. Games add the element of 'fun' in the lesson and it changes the learning environment to less stressful (Brewster\&Ellis,2002). Tengku, Rosniah and Stapa (2015) stated that implementing games into English lesson formed a source of enjoyment to students and supported by the responses from the students as they feel happy and enjoy while they play games using English. Apart from that, students feel confident to speak in English during the game. This finding supported by the study of Dewi, Kultsum and Armadi (2017), who stated students enjoyed the lesson implemented with language games, and they gained the confidence to speak English.

In conclusion, learners' attitudes towards learning English are vital to achieving language proficiency. If the learner has a positive attitude or perception towards learning English, most likely, the learner can achieve language proficiency. Charades played a part as a catalyst in the learning process. Through these findings and analysis of data, students that participate in this study did show improvement in their speaking skills and not forgetting; students also displayed a positive perception towards charades.

\subsection{Implication}

Charades can be seen as a game and a learning tool that educators can incorporate in their lesson plan. Through this research, educators can use charades in their speaking lesson plan. As Harmer (2001) stated, to encourage students to speak, an educator must emphasize the significance of language function, which means exposing students to real communication. So they could understand the use and function of the language.

Through this research, we can see charades do set a real-life communication within peers in a group rather than teaching students a structured speech. Before implementing charades in the classroom, students are given lessons on the particular topic where they are taught some vocabulary, and students apply that knowledge practically when they play charades.

Furthermore, charades are highly motivating and fun; hence, this helps teachers prevent making boring lesson plans. As using charades in speaking, lessons make the classroom student-centred. Moreover, an educator could adjust and adapt the game according to the learners' needs and age. In a nutshell, through this study, charades in teaching speaking skills effectively improve students' speaking skills and develop a positive attitude towards learning English.

\subsection{Recommendation}

This study can be used for different English language skills for further research. Moreover, this study is carried out on tertiary level students, and there were a limited number of students; hence the results cannot be generalized to a particular age group. Hence, the researcher can carry out this study on a different level of age group and more number of participants.

In this research, the researcher only carried out single group quasi-experimental research. To gain salient differences of results for further research, the researcher could have two quasi-experimental research, which involves control and experimental groups. 


\section{References}

[1] Afulaih, W.K. (2017). The impact of using games on developing Saudi female EFL and Language, 2(7),1-12.

[2] Amin, N., \& Nur, R. (2019). Using Guessing Game to Improve Speaking Ability of the Seventh Grade Students of SMP Negeri 3 Balusu.1-16.

[3] Avedon, M.E. \& B.S. Brian. (1971). Learning through Games. The Study of Games. New York: John Wiley \& Sons.

[4] Bailey, K. M. 2003. Practical English language teaching. New York: McGraw-Hill Contemporary.

[5] Baker, S. C., \& MacIntyre, P. D. (2003). The Role of Gender and Immersion in Communication and Second Language Orientations. In Z. Dörnyei (Eds.), Attitudes, Orientations and Motivations in Language Learning. Malden, MA: Blackwell publishing.

[6] Bonwell, C. C. \& Eison, J.A. (1991). Active learning: creating excitement in the classroom. Washington, D.C.: The George Washington University, School of Education and Human Development.

[7] Bransford, J.D., Brown, A. L., \& Cocking, R.R. (1999). How people learn: Brain, mind, experience, and school. Washington, D.C.: National Academy Press. Brocato.J,2014. Using Charades to Teach Presentation. ASEE Southeast Section Conference 1-8.

[8] Brown, S.1998. Current Task Based Language Teaching: Some Issues and Models. Paper presented at the Annual Meeting of the Ohio Teachers of English to Speakers of other Languages.

[9] Bueno, A., Madrid, D., \& McLaren, N. (2006.) TEFL in Secondary Education. Granada: Editorial Universidad de Granada.

[10] Bygate, M. (1998). Theoretical Perspectives on Speaking. Annual Review of Applied Linguistics.

[11] Byrne, D. (1986). Teaching Oral English. Cambridge: Cambridge University Press

[12] Byrne,D. (1995). Games Teaching Oral English. Harlow: Longman GroupUK Limited

[13] Byrne, D. (1986). Teaching Oral English. Cambridge: Cambridge University Press.

[14] Chambers, F. (1997). What do we mean by fluency? System 25(4):535-544

[15] Chaney, A.L., T.L. Burke. (1998). Teaching Oral Communication in Grades K-8 .Boston: Allyn and Bacon.

[16] Chen, I. (2005). Using Games to Promote Communicative Skills in Language Learning.

[17] Crookal, D. and R. L. (1990). Simulation, Gaming and Language Learning. New York: Newbury House.

[18] Crystal, D. (1977). Advanced Conversational English. London: Longman.

[19] Darmi, R. (2013).Learning English: Challenges for Malaysian languagelearners. ResearchGate 1-11.

[20] Dillenbourg. P. (1999). Collaborative-learning: Cognitive and computational approaches. Oxford: Elsevier.

[21] Dornyei, Z., \& Csizer, K. (1998). Ten commandments for motivating language learners: results of an empirical study. Language Teaching Research 2(3):203-229.

[22] Ellery, V. (2009). Creating Strategic Readers. New York: Library of Congress Cataloging-in-Publication Data.

[23] Ellis, R. (1987). Understanding Second Language Acquisition. Oxford: Oxford University Press.

[24] ESL undergraduates students in developing participation in speaking skills. Thesis Essays, UK.2018. Role Of The English Language In Malaysia English Language

[25] Essay.https://www.ukessays.com/essays/english-language/role-of-the-english-language-in-malaysia-english-language-essay.php?vref=1 [1 June 2020]. Fulton Publishers, New York.

[26] Ganapathi, U. R. (2012). The English language needs of biochemical science students at the University of Malaya. Degree Masters dissertation, University Malaya.

[27] Gardner, R. (1985). Social psychology and second language learning: The role of attitude and motivation. University of Western Ontario. London, UK.

[28] Gardner, R., \& Lambert, W. (1972). Attitudes and motivation in second-language learning. United States of America: Newbury House Publishers

[29] Garris,R, Ahlers, R, \&Driskell, J,E.(2002). Games, motivation, and learning: A research and practice model. Sage Publications 33( 4):441-467.

[30] Gaudart, H. (1987). English language teaching in Malaysia: A historical account. The English Teacher 16:17-36.

[31] Gill, S. K. (2005). Language policy in Malaysia: Reversing direction. Language Policy 4(3):241-260.

[32] Government of Malaya. (1956). Report of the education committee, 1956: The Razak report. Kuala Lumpur: Government Printers.

[33] Grenoble L.A, Whaley. L.J. (2006). Saving Languages: An Introduction to Language Hadfield, J. 1990. A Collection of Games and Activities for Low to Mid-Intermediate students of English. Intermediate Communication Games. Hong Kong: Thomus and Nelson and Nelson and Sons Ltd.

[34] Hadfield, J. (1990). Intermediate Communicative Game. Essex: Addison Wesley Longman Ltd.

[35] Hamzah, N. N. (2015). A Case Study of Using Communicative Language Games for UMS ESL Undergraduate Students in Developing Participation in Speaking Skills (Doctoral dissertation, Universiti Sains Malaysia).

[36] Hanapiah, M.F. (2004).English language and the language ofdevelopment: A Malaysian perspective. ResearchGate.

[37] Harmer, J. (2001). The Practice of English Language Teaching. Edinburgh: Pearson Education limited.

[38] Harmer, J. (2007). The Practice of English Language Teaching. Ed $4^{\text {th }}$. Edinburgh: Pearson

[39] Harmer, J. (2007). How to Teach English. Pearson Education Limited.

[40] HARRY AYERS. (2006). An A to Z Practical Guide to Learning Difficulties. David

[41] Heaton. J .(2004). Writing English Language Tests. New York: Cambridge University press.

[42] Hidayati, N, R. (2016). The use of charade game to teach vocabulary. Degree Final Year Project, Semarang State University.

[43] Hong, L. (2002). Using games in teaching English to young learners. The Internet TESL

[44] Horwitz, E. K. (2001). Language anxiety and achievement. Annual review of applied linguistics, 21, 112-126.

[45] Hossain, M. I., Yagamaran, K. S. A., Afrin, T., Limon, N., Nasiruzzaman, M., \& Karim, A. M. (2018). Factors influencing unemployment among fresh graduates: A case study in Klang Valley, Malaysia. International Journal of Academic Research in Business and Social Sciences, 8(9), 1494-1507.

[46] Hybel, D. 2001. Understanding Speaking Interaction. New York: Cambridge University Press.

[47] Hybel, D. 2001). Understanding Speaking Interaction. New York: Cambridge University Press. 
[48] Illeas.N.2014.When teachers use Malay to teach English: vignettes from Malaysian classrooms.file:///C:/Users/user/Downloads/WhenteachersuseMalaytoteachEnglish. pdf[20 May 2020].in English language for the primary stage.

[49] James F. Bauman \& Edward J. Kame'enui(eds). (2004). Keep the "Fun" in Fundamental Encouraging Word Awareness and Incidental Word Learning in the Classroom through Word Play.

[50] Jasin, A.K. (2005). Let's discuss and not make a fuss. Malaysian Business Malaysian Mazagine, Malaysia.

[51] Jean, G \& Simard. D. (2011). Grammar teaching and learning in L2: Necessary, but Boring? . Foreign Language Annals 44(30):467-494.

[52] Kruk. M. (2015). Variations in motivation, anxiety and boredom in learning English in Second Life.The Eurocall Review 23(2):25-39.

[53] Kukulska-Hulme, A., Pettit, J., Bradley, L., Carvalho, A. A., Herrington, A., Kennedy, D. M., \& Walker, A. (2011). Mature students using mobile devices in life and learning. International Journal of Mobile and Blended Learning (IJMBL), 3(1), 18-52.

[54] Lan. L. S. (1994).Fluency and accuracy in spoken English - implications for classroom practice in a bilingual context.The English Teacher 23:1-9. Language Learners. Addison Wesley Publishing Comp, Inc.

[55] Lin, Y. (20130. A sociocultural approach to the study of motivation and attitudes towards the learning of Mandarin Chinese in the U.S.: Secondary school students' perceptions. Columbia University. New York, USA.

[56] Linguistics 21:112-126.

[57] Majdah. (2018). Reluctance to speak in English among Community College students in Malaysia. [Phd thesis]. University Sains Malaysia.

[58] Mapesos, R, M. (2017).Traditional Approach. ResearchGate 1-3.

[59] Mcgonical, J. (2016). Reality is Broken. London: The Penguin Press.

[60] Mechraoui, A. (2011).A course of English for occupational purposes at the international Islamic University Malaysia: Meeting the English language needs of the industry.

[61] Middlehurst, R., \& Woodfield, S. (2004). The role of transnational, private, and for-profit provision in meeting global demand for tertiary education: mapping, regulation and impact: case study Malaysia.

[62] Ministry of Higher Education Malaysia .(2015). Executive Summary of Malaysia Education Blueprint 2015-2025 (Higher Education). Putrajaya, Malaysia: Ministry of Education Malaysia

[63] Mubaslat, M. (2012).The effect of using educational games on the students' achievement

[64] Munn,P \& Drevar, E. (1990). Using Questionnaires in Small-Scale Research. Edinburgh: Scottish Council.

[65] Musa, N.C, Lie, K.Y \& Azman, H. (2012). Exploring English Language Learning and Teaching In Malaysia. GEMA Online Journal of Language Studies 12(1):35-51.

[66] Musbalat, M.M. (2012). The effect of using educational games on the students' achievement in English Language for the primary stage.114

[67] Mysinchew.com. (2009). Bahasa Malaysia will remain as main medium of instruction in universities. http://www.mysinchew.com/node/31886[18 July 2020]. Nation, P. 1991. Fluency Improvement in a Second Language. RELC Journal 22(1):84-94.

[68] Nishanthi, R. 2018. The importance of learning English in Today World. International Journal of Trend in Scientific Research and Development 3(1):871-874.

[69] Noor Hashimah, A. A. (20070.ESL students' perspectives on language anxiety. PhD Universiti Putra Malaysia, Serdang.

[70] Nor.K,Razali. M,Talib.N,Ahmad.N.Sakarji.S.R,Saferdin.W.A.A\&Nor.A.Students' problems in learning English as a second language among MDAB students at UITM Malacca. International Journal of Humanities, Philosophy

[71] Normazidah, C. M., Lie, K. Y., \& Hazita, A. (2012). Exploring English language learning and teaching in Malaysia. GEMA Online Journal of Language Studies 12(1):31-51.

[72] Northrup. D. 2013. How English Became the Global Language. America :Palgrave Macmillan US.

[73] Nunan, D. (2003). Practical English Language Teaching. New York: McGraw- Hill.

[74] O'Malley, J. M., \& Pierce, L. V. (1996). Authentic Assessment For English Language Learners: Practical Approaches For Teachers Author: J. Michael O'Malley, Lorrain.

[75] Nunan, D. (1989). Designing Task for the communicative classroom. Cambridge: Cambridge University Press.

[76] Nunan. D.(1995). Language Teaching Methodology: A Textbook for teachers. New

[77] Nurlaela, L. (2015). Developing creative thinking skills in learning at Higher-Educational Institution of Teacher. UPI International Conference on Technical and Vocational Education and Training 114-119.

[78] Omar, A. H. (1992). The linguistic scenery in Malaysia. Kuala Lumpur: Dewan Bahasa dan Pustaka. Oxford: Basil Blackwell.

[79] Puspa, Belia Betri. (2017). The Implementation Of Guessing Game By Charades Application To Increase Speaking Ability At The Tenth Grade Students Of MA Darul Fikri In The Academic Year 2016/ 2017. Degree Thesis, Muhammadiyah University of Ponorogo.

[80] Quianthy, R. L. (1990). Communication is life: Essential college sophomore speaking and listening competencies. Annandale, VA: National Communication Association. Ramiza Darmi and Albion Peter.2013. English Language in Malaysian Education System: Its Existence and Implication. 3rd Malaysian Postgraduate Conference, NSW, Australia.

[81] Rao, G. (2019). Familiarity does not breed contempt: Generosity, discrimination, and diversity in Delhi schools. American Economic Review, 109(3), 774-809.

[82] Rebecca, R. (2016). English skills vital for all. The Star, Malaysia. Revitalization. New York: Cambridge University Press.

[83] Richards, J. C. (2005). Communicative language teaching today. SEAMEO Regional Language Centre.

[84] Ridge, B. (2004). Bangsa Malaysia and recent Malaysian English language policies. Current issues in language planning, 5(4), 407-423.

[85] Rixon, S. (1981). How to Use Games in Language Teaching. London: Macmillan.

[86] Saha, S. K., \& Singh, S. (2016). Collaborative learning through language games in ESL classroom. Language in India, 16(10), 180-189.

[87] Santri, P., Suryani, S., \& Dauyah, E. (2019, December). The Use of Charades Game to Improve Students Vocabulary Mastery. In Prosiding SEMDI-UNAYA (Seminar Nasional Multi Disiplin Ilmu UNAYA) (Vol. 3, No. 1, pp. 248-256). 
[88] Sari, D \& Chairani, N. (2017).The effectiveness of charades game towards students' vocabulary mastery at fourth grade of Sd Unggulan Aisyiyah Bantul in the academic year of 2016/2017.UAD TEFL International Conference 126-136.

[89] Sasidharan, A \& Eng,T. K. (2013). Pupils' and teachers' perceptions of a language board game, challenge. English Teacher 43(3):201-220.

[90] Savitri, A. S. (2013). The use of language games to improve the students' speaking ability of class VII a of SMP Ma'arif terpadu Muntilan in the academic year of 2012/2013. Yogyakarta State University, Yogyakarta.

[91] Schultz, M. \& A. Fisher. (1988). Interacting in the Language Classroom. Games for All Reasons. Massachusetts: Addison-Wesley Publishing Company.

[92] Shaaban, K. A., \& Ghaith, G. (2000). Student motivation to learn English as a foreign language. Foreign Language Annals, 33(6), 632-644.

[93] Shahini, G., \& Shahamirian, F. (2017). Improving English speaking fluency: The role of six factors. Advances in Language and Literary Studies, 8(6), 100-104.

[94] Spolsky, B. (1989). Conditions for second language learning. Oxford: Oxford University Press.

[95] Tanaraj,M.R.( 2014). The use Of different varieties of Malaysian English among female teenage Malaysians. [Masters thesis]. University of Malaya.

[96] Teare, Barry. (2006). Successful Provision for Able and Talented Children. London: Network Continuum Education.

[97] Ming, T. S., Ling, T. S., \& Jaafar, N. M. (2011). Attitudes and motivation of Malaysian secondary students towards learning English as a second language: A case study. 3L: Language, Linguistics, Literature ${ }^{\circledR}, 17(1)$.

[98] Thiagarajan, S., et al. (1974). Instructional Development for Training Teacher of Exceptional Children. Bloomington: Indiana University. Thornbury. S. (2005). Ho(w to Teach Speaking. United States of America: Pearson.

[99] Thomson. R.I. (2015). Fluency.The Handbook of Pronunciation. New Jersey:Wiley

[100]Ting, S.H , Marzuki, E, Chuah, K.M , Misieng. J \& Jerome .C. (2017). Employers' Views On the Importance of English Proficiency And Communication Skill For Employability In Malaysia. Indonesian Journal of Applied Linguistics, 7(2), 315-327.

[101]Too,W.K.2017.English language teaching and policies at the tertiary level in Malaysia. Researchgate 109-129.

[102]Torky,S.A.E.2006.Thesis Phd,Ain Shams University. Uberman, A. (1998). The use of games for vocabulary presentation and revision. English Teaching Forum, 36(1):20-27.

[103]Tsui, A. B., \& Tollefson, J. W. (2004). Medium of instruction policies: Which agenda? Whose agenda . Mahwah, NJ: Lawrence Erlbaum Associates Inc.

[104]Vanderkevent.(1990). Teaching Speaking and Component of Speaking. New York: Cambridge University Press. Vocabulary Mastery.Semdi Unaya 248-256.

[105]Vygotsky, LS. (1978). Mind in society: the development of higher psychological processes. Cambridge: Harvard University Press.

[106]Wahyuni, S \& Yulianti, F. (2016).The use of guessing game to improve student's speaking skills. English Education Journal 3(2):12-22.

[107]Wittgenstein, Ludwig. (1972). Philosophical Investigations, trans. G. E. M. Anscombe.

[108]Woodrow, L. (2006). Anxiety and speaking English as a second language. RELC Journal

[109]Yano, Y. (2003). Communicative competence and English as an international language. Intercultural Communication Studies. York: Phoenix.

[110]Yahoui, N.(2012). The Effectiveness of Language Games in Improving Learners' Vocabulary. Biskra: University of Biskra. Zhu, D. (2012). Using games to improve students' communicative ability. Journal of Language Teaching and Research, 3(4):801-805.

[111]Yuan. F, Ellis. R .(2003). The Effects of Pre-Task Planning and On-Line Planning on Fluency, Complexity and Accuracy in L2 Monologic Oral Production. Applied Linguistics 24(1), 1-27.

[112]Zareian, G., \& Jodaei, H. 2015). Motivation in Second Language Acquisition: A State of the Art Article. International Journal Social Science \& Education 5(2): 295-308.

\section{Appendices}

\section{APPENDIX A}

A. Pre and post test

Topic: Descriptions (Presentation)

Instruction: Describe your favourite person and object.

Describe your favourite person

- Height

- Facial

- Age

- Attire

Describe two objects and compare it (Must be same object from different product)

- Colour

- Size

- Material

- Function

- Price

- Quality 
- Special features

APPENDIX B

Assessment Rubric

College Community

\begin{tabular}{|c|c|c|c|c|c|c|c|}
\hline \multirow[t]{2}{*}{ Criteria } & \multirow{2}{*}{$\begin{array}{l}\text { Sub } \\
\text { Criteria/Aspect } \\
\text { S }\end{array}$} & \multirow[t]{2}{*}{ Weightage } & 5 & 4 & 3 & 2 & 1 \\
\hline & & & Excellent & Good & Satisfactory & Weak & Very Weak \\
\hline \multirow[t]{4}{*}{$\begin{array}{l}1 . \\
\text { DESCRIPTIONS } \\
(40 \%)\end{array}$} & $\begin{array}{l}\text { Describe } \\
\text { people by their } \\
\text { physical } \\
\text { features, for } \\
\text { example, } \\
\text { height, age, } \\
\text { and facial } \\
\text { features. }\end{array}$ & $10 \%$ & $\begin{array}{l}\text { Presents } \\
\text { adequate } \\
\text { relevant content } \\
\text { and gives } \\
\text { elaboration and } \\
\text { insight to the } \\
\text { intent. }\end{array}$ & $\begin{array}{l}\text { Presents } \\
\text { adequate } \\
\text { relevant } \\
\text { content and } \\
\text { expresses } \\
\text { intent but } \\
\text { without } \\
\text { elaboration. }\end{array}$ & $\begin{array}{l}\text { Presents } \\
\text { minimally } \\
\text { adequate } \\
\text { content but is } \\
\text { a little } \\
\text { inappropriate } \\
\text { to the intent. }\end{array}$ & $\begin{array}{l}\text { Presents } \\
\text { inadequate or } \\
\text { vague } \\
\text { content which } \\
\text { is } \\
\text { inappropriate } \\
\text { to the intent } \\
\text { some of the } \\
\text { time. }\end{array}$ & $\begin{array}{l}\text { Presents very } \\
\text { vague content } \\
\text { and } \\
\text { inappropriate } \\
\text { to the intent } \\
\text { most of the } \\
\text { time. }\end{array}$ \\
\hline & $\begin{array}{l}\text { Describe } \\
\text { people by their } \\
\text { attire }\end{array}$ & $10 \%$ & $\begin{array}{l}\text { Presents } \\
\text { adequate } \\
\text { relevant content } \\
\text { and gives } \\
\text { elaboration and } \\
\text { insight to the } \\
\text { intent. }\end{array}$ & $\begin{array}{l}\text { Presents } \\
\text { adequate } \\
\text { relevant } \\
\text { content and } \\
\text { expresses } \\
\text { intent but } \\
\text { without } \\
\text { elaboration. }\end{array}$ & $\begin{array}{l}\text { Presents } \\
\text { minimally } \\
\text { adequate } \\
\text { content but is } \\
\text { a little } \\
\text { inappropriate } \\
\text { to the intent }\end{array}$ & $\begin{array}{l}\text { Presents } \\
\text { inadequate or } \\
\text { vague } \\
\text { content which } \\
\text { is } \\
\text { inappropriate } \\
\text { to the intent } \\
\text { some of the } \\
\text { time. }\end{array}$ & $\begin{array}{l}\text { Presents very } \\
\text { vague content } \\
\text { and } \\
\text { inappropriate } \\
\text { to the intent } \\
\text { most of the } \\
\text { time. }\end{array}$ \\
\hline & $\begin{array}{l}\text { Describe an } \\
\text { object and a } \\
\text { product by its } \\
\text { features/appea } \\
\text { rance for } \\
\text { example, } \\
\text { colour, size } \\
\text { and materials }\end{array}$ & $10 \%$ & $\begin{array}{l}\text { Presents } \\
\text { adequate } \\
\text { relevant content } \\
\text { and gives } \\
\text { elaboration and } \\
\text { insight to the } \\
\text { intent. }\end{array}$ & $\begin{array}{l}\text { Presents } \\
\text { adequate } \\
\text { relevant } \\
\text { content and } \\
\text { expresses } \\
\text { intent but } \\
\text { without } \\
\text { elaboration }\end{array}$ & $\begin{array}{l}\text { Presents } \\
\text { minimally } \\
\text { adequate } \\
\text { content but is } \\
\text { a little } \\
\text { inappropriate } \\
\text { to the intent }\end{array}$ & $\begin{array}{l}\text { Presents } \\
\text { inadequate or } \\
\text { vague } \\
\text { content which } \\
\text { is } \\
\text { inappropriate } \\
\text { to the intent } \\
\text { some of the } \\
\text { time. }\end{array}$ & $\begin{array}{l}\text { Presents very } \\
\text { vague content } \\
\text { and } \\
\text { inappropriate } \\
\text { to the intent } \\
\text { most of the } \\
\text { time. }\end{array}$ \\
\hline & $\begin{array}{l}\text { Compare } \\
\text { objects/ } \\
\text { products by } \\
\text { their features } \\
\text { appearance for } \\
\text { example, } \\
\text { colour, size } \\
\text { and materials }\end{array}$ & $10 \%$ & $\begin{array}{l}\text { Presents } \\
\text { adequate } \\
\text { relevant content } \\
\text { and gives } \\
\text { elaboration and } \\
\text { insight to the } \\
\text { intent. }\end{array}$ & $\begin{array}{l}\text { Presents } \\
\text { adequate } \\
\text { relevant } \\
\text { content and } \\
\text { expresses } \\
\text { intent but } \\
\text { without } \\
\text { elaboration }\end{array}$ & $\begin{array}{l}\text { Presents } \\
\text { minimally } \\
\text { adequate } \\
\text { content but is } \\
\text { a little } \\
\text { inappropriate } \\
\text { to the intent }\end{array}$ & $\begin{array}{l}\text { Presents } \\
\text { inadequate or } \\
\text { vague } \\
\text { content which } \\
\text { is } \\
\text { inappropriate } \\
\text { to the intent } \\
\text { some of the } \\
\text { time. }\end{array}$ & $\begin{array}{l}\text { Presents very } \\
\text { vague content } \\
\text { and } \\
\text { inappropriate } \\
\text { to the intent } \\
\text { most of the } \\
\text { time. }\end{array}$ \\
\hline
\end{tabular}




\begin{tabular}{|c|c|c|c|c|c|c|c|}
\hline $\begin{array}{l}2 . \\
\text { ORGANISATION } \\
\qquad(10 \%)\end{array}$ & $\begin{array}{l}\text { Coherence and } \\
\text { Cohesion }\end{array}$ & $10 \%$ & $\begin{array}{l}\text { Presents and } \\
\text { sequence ideas } \\
\text { coherently and } \\
\text { cohesively } \\
\text { almost all the } \\
\text { time. There is a } \\
\text { logical } \\
\text { progression of } \\
\text { ideas. }\end{array}$ & $\begin{array}{l}\text { Presents and } \\
\text { sequence } \\
\text { ideas } \\
\text { coherently } \\
\text { and } \\
\text { cohesively } \\
\text { most of the } \\
\text { time. There is } \\
\text { a logical } \\
\text { progression } \\
\text { of ideas. }\end{array}$ & $\begin{array}{l}\text { Presents and } \\
\text { sequence } \\
\text { ideas } \\
\text { coherently } \\
\text { and } \\
\text { cohesively } \\
\text { some the } \\
\text { time. There } \\
\text { is } \\
\text { intermittent } \\
\text { lack of } \\
\text { logical } \\
\text { progression } \\
\text { of ideas }\end{array}$ & $\begin{array}{l}\text { Presents and } \\
\text { sequence } \\
\text { ideas with a } \\
\text { lack of } \\
\text { coherence } \\
\text { and cohesion. } \\
\text { There is a } \\
\text { logical } \\
\text { progression } \\
\text { of the ideas. }\end{array}$ & $\begin{array}{l}\text { Presents and } \\
\text { sequence } \\
\text { ideas } \\
\text { incoherently. } \\
\text { Ideas do not } \\
\text { flow logically. }\end{array}$ \\
\hline $\begin{array}{c}\text { 3.LANGUAGE } \\
(40 \%)\end{array}$ & Fluency & $20 \%$ & $\begin{array}{l}\text { Speaks } \\
\text { intelligibly, very } \\
\text { smoothly and } \\
\text { effortlessly } \\
\text { almost all the } \\
\text { time. } \\
\text { Pronunciation } \\
\text { and intonation } \\
\text { are accurate } \\
\text { almost all the } \\
\text { time. }\end{array}$ & $\begin{array}{l}\text { Speaks } \\
\text { intelligibly, } \\
\text { smoothly and } \\
\text { with little } \\
\text { effort and self- } \\
\text { correction } \\
\text { most of the } \\
\text { time. } \\
\text { Pronunciation } \\
\text { and intonation } \\
\text { are accurate } \\
\text { much of the } \\
\text { time. }\end{array}$ & $\begin{array}{l}\text { Speaks with } \\
\text { occasionally } \\
\text { hesitation, } \\
\text { repetition and } \\
\text { successful } \\
\text { self- } \\
\text { correction. } \\
\text { Pronunciation } \\
\text { and } \\
\text { intonation are } \\
\text { accurate } \\
\text { occasionally. }\end{array}$ & $\begin{array}{l}\text { Speaks with a } \\
\text { lot of } \\
\text { hesitation, } \\
\text { repetition and } \\
\text { some false } \\
\text { starts. } \\
\text { Pronunciation } \\
\text { and } \\
\text { intonation are } \\
\text { seldom } \\
\text { accurate. }\end{array}$ & $\begin{array}{l}\text { Speaks with } \\
\text { numerous } \\
\text { long pauses } \\
\text { and false } \\
\text { starts, and } \\
\text { hardly able to } \\
\text { proceed. } \\
\text { Pronunciation } \\
\text { and } \\
\text { intonation are } \\
\text { hardly } \\
\text { accurate. }\end{array}$ \\
\hline & Accuracy & $20 \%$ & $\begin{array}{l}\text { Uses varying sentence } \\
\text { patterns with no major } \\
\text { and hardly any minor } \\
\text { grammatical errors. } \\
\text { Has a good range of } \\
\text { vocabulary. }\end{array}$ & $\begin{array}{l}\text { Uses simple } \\
\text { sentence patterns } \\
\text { with no major and } \\
\text { some minor } \\
\text { grammatical } \\
\text { errors. } \\
\text { Has a fair range of } \\
\text { vocabulary. }\end{array}$ & $\begin{array}{l}\text { Uses simple } \\
\text { sentence patterns } \\
\text { with some major } \\
\text { and several minor } \\
\text { grammatical } \\
\text { errors. } \\
\text { Has limited range } \\
\text { of simple } \\
\text { vocabulary }\end{array}$ & \begin{tabular}{|l} 
Uses generally \\
inaccurate \\
language with \\
numerous major \\
and minor \\
grammatical \\
errors. \\
Has a limited \\
range of simple \\
vocabulary. \\
\end{tabular} & \begin{tabular}{|l} 
Uses inaccurate \\
language with \\
hardly any \\
grammatically \\
correct utterance. \\
Has very few and \\
simple vocabulary.
\end{tabular} \\
\hline $\begin{array}{l}\text { 4. PRESENTATIO } \\
\text { N SKILLS } \\
10 \%\end{array}$ & $\begin{array}{l}\text { Non-verbal } \\
\text { Skills }\end{array}$ & $10 \%$ & $\begin{array}{l}\text { Speaks audibly most of } \\
\text { the time, pausing } \\
\text { appropriately. } \\
\text { Maintains some eye } \\
\text { contact with audience } \\
\text { most of the time. }\end{array}$ & $\begin{array}{l}\text { Speaks audibly } \\
\text { most of the time, } \\
\text { pausing } \\
\text { appropriately. } \\
\text { Maintains some } \\
\text { eye contact with } \\
\text { the audience some } \\
\text { of the time. }\end{array}$ & $\begin{array}{l}\text { Speaks inaudibly } \\
\text { most of the time. } \\
\text { Maintains very } \\
\text { little eye contact } \\
\text { with the audience. }\end{array}$ & $\begin{array}{l}\text { Speaks inaudibly } \\
\text { most of the time. } \\
\text { Maintains very } \\
\text { little eye contact } \\
\text { with the } \\
\text { audience. }\end{array}$ & $\begin{array}{l}\text { Speaks inaudibly } \\
\text { almost all the } \\
\text { time. Maintains } \\
\text { no eye contact } \\
\text { with the } \\
\text { audience. }\end{array}$ \\
\hline
\end{tabular}

Adapted from Jabatan Pengurusan Kolej Komuniti (JPKK). 


\section{APPENDIX C}

Questionnaire

Answer all the questions.

\begin{tabular}{|c|c|c|c|c|}
\hline No & Statements & Agree & Neutral & Disagree \\
\hline 1 & The game was enjoyable. & & & \\
\hline 2 & The length of time for playing the game was suitable. & & & \\
\hline 3 & The rules of the game were clear. & & & \\
\hline 4 & I took a long time to understand how to play the game. & & & \\
\hline 5 & I like the interaction with other players during the game. & & & \\
\hline 6 & I am active during the game. & & & \\
\hline 7 & The game keeps me alert. & & & \\
\hline 8 & I enjoy playing the games & & & \\
\hline 9 & The game motivates me to learn English. & & & \\
\hline 10 & The game motivates me to use English. & & & \\
\hline 11 & I feel confident to speak in English during the game. & & & \\
\hline 12 & The game encourages teamwork. & & & \\
\hline
\end{tabular}

Adapted from (Sasidharan \&Eng,2013)

APPENDIX D

D.Excerpt of oral presentation of student number 5

"Erm...the person.....Shahmi...........My best friend.He is a teenager. He has coklat air.........He have short hair.....She ermm have short air. She have long eyes and the black eyes."

Excerpt of pretest

"The person I admire is Shahmi,he is a very good friend of mine. He is 18 years old and he is a Malaysian. He height is $182 \mathrm{~cm}$. He has a short brown curly hair. He also has small black eyes. His nose is pointed. He like to wear black shirt and long pants with canvas shoes.

Excerpt of post test 